Viacheslav V. Lytvynenko (Prague)

(iD) https://orcid.org/0000-0001-5519-8980

\title{
Scribal Habits in the Slavonic Manuscripts with Athanasius' Second Oration against the Arians*
}

$\mathrm{T}$

extual scholars have long recognized that their manuscripts contain residues of scribal practices and attitudes, and therefore knowledge of documents should precede final judgment upon readings ${ }^{1}$. With this idea in mind, this article will examine the scribal habits in ten manuscripts that contain the Slavonic version of Athanasius' Orations against the Arians. Naturally, the aim of this study is to bring more precision concerning the textual transmission of this writing in the Slavonic manuscripts and thus shed light on the way the Orations were copied and read in medieval times. The questions it will ask are whether we can discern any patterns in the way the scribes changed the text, whether any such changes could be theologically motivated and in what way may they be related to the local contexts in which the Orations were copied.

I will begin with a few general remarks on the Slavonic text of the Orations and then examine the statistical data for each of the ten manuscripts according to eleven scribal categories. I will conclude with a more detailed discussion of scribal habits in two specific manuscripts that represent the most important cases of textual transmission for my purposes. The study as a whole will be based on my critical edition of the Second Oration ${ }^{2}$ and accompanied with several statistical tables throughout the article and in the Appendix. The new material presented in this article is designed to supplement my previous work and also encourage similar studies for the entire corpus of Slavonic Orations.

\footnotetext{
* This study represents research funded by the Czech Science Foundation as the project GAČR 17-07880S "Athanasius of Alexandria, Epistula ad episcopos Aegypti et Libyae: Critical Edition of the Old Slavonic Version", and by the Charles University Research Centre program No. 204053.

${ }^{1}$ B.F. Westcott, F.J.A. Hort, The New Testament in the Original Greek, vol. II, ${ }^{2}$ London 1896, p. 31. ${ }^{2}$ Athanasius of Alexandria, Oratio II contra Arianos. Old Slavonic Version and English Translation, ed. et trans. V.V. Lytvynenko, Turnhout 2019 [= PO, 248 (56.3)] (cetera: Oratio II contra Arianos). On the issue of Slavonic translation and the manuscripts, see p. 354-395.
} 
Three Orations against the Arians (CPG 2093; henceforth CA I, II, III) is the largest and most significant theological work of Athanasius of Alexandria (ca. A.D. 296/298-373)3. Written during his exile in Rome between A.D. 339 and 345, it was directed against Arius (ca. A.D. 256-336) and his sympathizers who denied Christ's divinity and the doctrine of the Trinity. In A.D. 907, Athanasius' Orations along with his Epistle to the Bishops of Egypt and Libya CPG 2092 ${ }^{4}$ (written ca. A.D. 356 and called the Fourth Oration in the Slavonic corpus; henceforth CA IV) were translated into Slavonic by Constantine of Preslav in Eastern Bulgaria. Today we have 10 Slavonic MSS ranging from the $15^{\text {th }}$ to $17^{\text {th }}$ centuries that preserve this work, and they include the following:

\begin{tabular}{||c|l|l|}
\hline Sigla & \multicolumn{1}{|c|}{ Manuscripts } & \multicolumn{1}{c|}{ Time } \\
\hline A & RNB, St. Petersburg, Pog. 968 & 1489 \\
\hline B & RGB, Moscow, Ovč. F.209, 791 & $15^{\text {th }}$ c. \\
\hline C & RGB, Moscow, Nik. F.199, 59 & Late $15^{\text {th }}-$ early $16^{\text {th }}$ c. \\
\hline D & RGB, Moscow, Vol. F.113, 437 & 1489 \\
\hline E & GIM, Moscow, Sin. 20 & Late 1480 s - early 1490 s \\
\hline F & RNB, St. Petersburg, Sol. 63 & $16^{\text {th } c . ~}$ \\
\hline G & RNB, St. Petersburg, Sof. VMČ 1321 & No later than 1541 \\
\hline H & GIM, Moscow, Sin. Tsa. VMČ 180 & No later than 1554 \\
\hline K & GIM, Moscow, Sin. Usp. VMČ 994 & No later than 1552 \\
\hline L & RGB, Moscow, Ovč. F.209, 99 & Mid-17 th c. \\
\hline \hline
\end{tabular}

My study of the Second Oration ${ }^{5}$ allowed me to establish that four of the ten MSS in our possession (ABCD) were copied independently from the same Bulgarian protograph, while the other six (EFGHKL) descend from $\mathrm{D}$ and form

\footnotetext{
${ }^{3}$ Athanasius Werke, vol. I.1, Die dogmatischen Schriften, Lfg. 2, Orationes I et II contra Arianos, ed. K. Metzler, K. Savvidis, Berlin-New York 1998; Athanasius Werke, vol. I.1, Die dogmatischen Schriften, Lfg. 3, Oratio III contra Arianos, ed. K. Metzler, K. Savvidis, Berlin-New York 2000. ${ }^{4}$ Athanasius Werke, vol. I.1, Die dogmatischen Schriften, Lfg. 1, Epistula ad episcopos Aegypti et Libyae, ed. K. Metzler, K. Savvidis, Berlin-New York 1996.

${ }^{5}$ Oratio II contra Arianos, p. 371-395 (stemma codicum is on p. 395).
} 
a separate group of MSS. Within this group, $\mathrm{E}$ is copied directly from $\mathrm{D}$, and $\mathrm{G}$ is copied directly from E. Furthermore, $\mathrm{F}$ is copied partly from $\mathrm{C}$ ( $C A$ chs. 1-38), and partly from $\mathrm{E}$ (CA chs. 39-82), while HK are copied from G, and L is copied from $\mathrm{K}$. In my analysis of the scribal habits, I will first consider the primary group of MSS (ABCD), and then the secondary one (EFGHKL).

\section{Statistical analysis}

In this section, I would like to explore each of the ten MSS according to the following eleven categories or scribal features in the Second Oration: (1) omissions, (2) additions, (3) substitutions, (4) transpositions, (5) non-sense readings, (6) marginal corrections, (7) marginal notes, (8) deletions, (9) erasures, (10) interlinear corrections, and (11) corrections within the text. For each MS, I will first provide a summary table of the scribal habits according to these eleven categories and then make a few comments that will try to make sense of the statistical data at hand. Before I do that, however, I owe an explanation of how the tables should be read.

For each of the eleven categories, the tables include one or more numbers in the right. The first number gives the total sum of occurrences for a particular scribal feature, and any other numbers that follow are separated by a slash and mean one of two things. First, in the section with omissions and additions, the second number after the slash means the total estimate of omitted and added letters. For example, if the table for the scribe of MS A shows 51/96 of omissions and 23/166 of additions, it means that he made 51 cases of omission resulting in 96 omitted letters, and 23 cases of addition resulting in 166 added letters. To have this kind of statistics allows us to see how many elements the scribe omits and adds, as well as how often he does that. Second, there are three more types of numbers that need to be understood according to the following indicators next to them: ${ }^{\mathrm{R}}$, , underlining. Here, letter ${ }^{\mathrm{R}}$ means a case of redundancy, letter ${ }^{\mathrm{L}}$ means a marginal note that is two or more letters long, and any underlined number means a deliberate/significant change in the text. Thus, again, if the table for the scribe of MS A shows $23 / 166 / 6^{\mathrm{R}} / \underline{1}$ of additions, it means that he had 23 cases of addition resulting in 166 added letters, and out of 23 cases of addition there are $6^{\mathrm{R}}$ cases where he added a redundant letter or syllable, and there is 1 case where he made a deliberate/significant addition in the text. Similarly, if the table for the scribe of MS K shows $16 / 12^{\mathrm{L}}$ cases of marginal notes, it means that he made 16 marginal notes, of which $12^{\mathrm{L}}$ cases are notes two or more letters long.

The ten summary tables offered in this section are also part of the longer table in the Appendix. The longer table further indicates all individual cases for each of the eleven scribal categories in the MSS. 


\subsection{Primary group of MSS}

\section{Scribe of MS A}

\begin{tabular}{|l|l|}
\hline \hline Omissions & $51 / 96$ \\
\hline Additions & $23 / 166 / 6^{\mathrm{R}} / \underline{1}$ \\
\hline Substitutions & $23 / \underline{1}$ \\
\hline Transpositions & 2 \\
\hline Non-sense readings & 2 \\
\hline Marginal corrections & 23 \\
\hline Marginal notes & 5 \\
\hline Deletions & $20 / 16^{\mathrm{R}}$ \\
\hline Erasures & $3 / 1^{\mathrm{R}}$ \\
\hline Interlinear corrections & 30 \\
\hline Corrections within the text & 0 \\
\hline
\end{tabular}

Based on the above figures, the most prominent feature that distinguishes this scribe is his making additions (166), and to a much lesser extent omissions (96). Next in number is his habit of using interlinear corrections (30) that appear more frequently than his corrections in the margins (23). When compared with the other three scribes from the primary group of MSS, he omits the least number of letters (96 vs $211,273,455)$, and has the lowest number of substitutions (23 vs $91,116,142)$ and transpositions ( 2 vs $3,5,20)$. He shares about the same number of added letters as the scribe of MS C (166 vs 164), which is higher than in the scribe of MS D (128) but significantly lower than in the scribe of MS B (509). These figures generally make him the best MS out of four that were copied directly from the Bulgarian protograph.

\section{Scribe of MS B}

\begin{tabular}{|l|l|}
\hline Omissions & $138 / 455$ \\
\hline Additions & $102 / 509 / 7^{\mathrm{R}} / \underline{3}$ \\
\hline Substitutions & $142 / \underline{4}$ \\
\hline Transpositions & 3 \\
\hline Non-sense readings & 15 \\
\hline
\end{tabular}




\begin{tabular}{|l|l||}
\hline Marginal corrections & 12 \\
\hline Marginal notes & $3 / 2^{\mathrm{L}}$ \\
\hline Deletions & $3 / 1^{\mathrm{R}}$ \\
\hline Erasures & 1 \\
\hline Interlinear corrections & 10 \\
\hline Corrections within the text & 0 \\
\hline
\end{tabular}

This scribe tends to add and omit very often. In fact, the number of omitted and added elements is enormous when compared with the other three MSS (455 vs $96,211,273$ for omissions, and 509 vs 128, 166, 164 for additions). Besides the high frequency of omissions (138 vs 51, 99, 119), he omits larger portions of text than the other scribes do, and sometimes fails to copy the middle part of words, and not just their first or last letters. Oftentimes, this leads him to create more non-sense readings than the other scribes ( $15 \mathrm{vs} 1,2,4)$. The number of substitutions is also very high $(142$ vs $21,91,116)$, though he rarely introduces deliberate textual changes ( 4 vs 1, 13, 36). For corrections, he uses the margins (12) almost as often as he writes the corrections on top of words (10). He rarely makes transpositions (3), and his deletions and erasures are very few (3 and 1). These low figures with respect to corrections, make this MS appear visibly as the cleanest one of the four.

\section{Scribe of MS C}

\begin{tabular}{|l|l|}
\hline Omissions & $99 / 211 / \underline{1}$ \\
\hline Additions & $39 / 164 / 2^{\mathrm{R}}$ \\
\hline Substitutions & $91 / \underline{13}$ \\
\hline Transpositions & 5 \\
\hline Non-sense readings & 1 \\
\hline Marginal corrections & 42 \\
\hline Marginal notes & 2 \\
\hline Deletions & $11 / 5^{\mathrm{R}}$ \\
\hline Erasures & 5 \\
\hline Interlinear corrections & 23 \\
\hline Corrections within the text & 0 \\
\hline
\end{tabular}


This scribe makes more omissions (211) than he does additions (164) and substitutions (91), and when compared with the other scribes, he is second among them with respect to all three of these categories. There are 13 cases of what might be deliberate substitutions and one deliberate omission, which makes him third among the others. He makes 5 transpositions vs 2, 3, 20 in other MSS, and when he corrects himself, he makes the marginal corrections (42) almost twice as often as he does the interlinear corrections (23). The same is true of the deletions that approximate twice as many (11) as the erasures (5).

\section{Scribe of MS D}

\begin{tabular}{|l|l|}
\hline Omissions & $119 / 273 / \underline{\underline{3}}$ \\
\hline Additions & $63 / 128 / 3^{\mathrm{R}} / \underline{12}$ \\
\hline Substitutions & $116 / \underline{36}$ \\
\hline Transpositions & 20 \\
\hline Non-sense readings & 4 \\
\hline Marginal corrections & 115 \\
\hline Marginal notes & 0 \\
\hline Deletions & $11 / 7^{\mathrm{R}}$ \\
\hline Erasures & 24 \\
\hline Interlinear corrections & 62 \\
\hline Corrections within the text & 4 \\
\hline
\end{tabular}

This scribe makes a lot of omissions $(273$ vs $96,211,455)$ and tends to have about the same number of added elements (128 vs $164,166,509)$ as he has substitutions (116 vs $23,91,142)$. When compared with the other scribes, he makes the largest number of what might be deliberate changes ( 51 vs $2,7,14)$, as well as transpositions ( 20 vs $2,3,5$ ), marginal corrections (115 vs $12,23,42$ ), erasures (24 vs $1,3,5)$, and interlinear corrections (62 vs 10, 23, 30). From the visual standpoint, there is rarely a folio that has nothing written in the margins or has no interlinear corrections on it. This MS will be discussed in much more detail later. 


\subsection{Secondary group of MSS}

Scribe of MS E

\begin{tabular}{|l|l|}
\hline Omissions & $35 / 61 / \underline{1}$ \\
\hline Additions & $18 / 52$ \\
\hline Substitutions & 21 \\
\hline Transpositions & 2 \\
\hline Non-sense readings & 1 \\
\hline Marginal corrections & 58 \\
\hline Marginal notes & 0 \\
\hline Deletions & $63 / 23^{\mathrm{R}}$ \\
\hline Erasures & 14 \\
\hline Interlinear corrections & 120 \\
\hline Corrections within the text & 8 \\
\hline
\end{tabular}

This scribe copied directly from the scribe of MS D, who then checked both MSS and often made identical corrections in each of them. For that reason, it is not always easy to say which correction belongs to which scribe, but oftentimes, the same correction that is made in the margin (115) in MS D is then made in the form of an interlinear correction (120) in MS E. One significant feature in the scribe of MS E is his exercise of deletions: 63 vs 11 in the scribe of MS D, and vs 1, $1,3,5,6,8,11,20$ in the other MSS. His use of erasures is less common than in the scribe of MS D (14 vs 24), but more common than in all the other MSS (14 vs 0, $0,0,1,1,3,5,8)$, and he makes more corrections within the text than the other scribes do ( 8 vs $0,0,0,0,1,1,1,4,7)$. He omits about the same number of elements (61) as he adds them (52), and introduces 21 substitutions of which only 1 seems to be deliberate. The number of transpositions (2) and non-sense reading (1) is very small.

Scribe of MS F

\begin{tabular}{|l|l|}
\hline Omissions & $61 / 154 / \underline{1}$ \\
\hline Additions & $48 / 77 / 1^{\mathrm{R}}$ \\
\hline Substitutions & $51 / \underline{3}$ \\
\hline Transpositions & 13 \\
\hline
\end{tabular}




\begin{tabular}{|l|l||}
\hline Non-sense readings & 0 \\
\hline Marginal corrections & 22 \\
\hline Marginal notes & 0 \\
\hline Deletions & $8 / 2^{\mathrm{R}}$ \\
\hline Erasures & 8 \\
\hline Interlinear corrections & 11 \\
\hline Corrections within the text & 1 \\
\hline
\end{tabular}

Despite the fact that the same hand copied both (and about equal) parts of this MS - chs. 1-38 from MS C, and chs. 39-82 from MS E - its first part contains considerably more cases of omissions (41 vs 21 ), additions (37 vs 11), substitutions (41 vs 10 ), and transpositions ( 11 vs 2 ) than the second part. There are also more erasures ( 7 vs 1 ) and marginal corrections (16 vs 6 ) in the first part than in the second, and only deletions ( 2 vs 6 ) and interlinear corrections (4 vs 7) figure more prominently in the second part than in the first. One explanation for these unequal statistics might be related to the possibility that the scribe took a significant break to rest before switching to the second part of the MS, while being more tired (and therefore sloppier) during his work on the first part that followed on twice as much work of copying the first Oration. When compared with the other MSS that ascend to MS E, the scribe of MS F is second in the number of additions ( 77 vs $0,12,12,82$ ), third in the number of omissions (154 vs 2 , $36,154,321)$, fourth in the number of substitutions (51 vs $6,18,2654)$, and fifth in the number of transpositions ( 13 vs $0,0,0,7$ ).

\section{Scribe of MS G}

\begin{tabular}{|l|l|}
\hline Omissions & $21 / 36$ \\
\hline Additions & $7 / 12 / 2^{\mathrm{R}}$ \\
\hline Substitutions & 18 \\
\hline Transpositions & 0 \\
\hline Non-sense readings & 3 \\
\hline Marginal corrections & 6 \\
\hline Marginal notes & 1 \\
\hline Deletions & $6 / 3^{\mathrm{R}}$ \\
\hline
\end{tabular}




\begin{tabular}{|l|l|}
\hline Erasures & 0 \\
\hline Interlinear corrections & 14 \\
\hline Corrections within the text & 1 \\
\hline
\end{tabular}

This scribe copied directly from MS E, and his copy is the second best one within the secondary group of MSS when it comes to omissions (36 vs 2, 61, 154, $154,321$ ), additions ( 12 vs $0,12,52,77,82)$, and substitutions (18 vs $6,21,26,51$, 54). He makes omissions (36) about two times as often as he does additions (12) and substitutions (18), and there are no transpositions and deliberate changes in the text. For corrections, he uses superscriptions more frequently (14) than he does marginal corrections (6), and half of his deletions $\left(6 / 3^{\mathrm{R}}\right)$ take place when he needs to get rid of the syllables that he copied twice by mistake.

\section{Scribe of MS H}

\begin{tabular}{|l|l|}
\hline Omissions & $1 / 2$ \\
\hline Additions & 0 \\
\hline Substitutions & 6 \\
\hline Transpositions & 0 \\
\hline Non-sense readings & 0 \\
\hline Marginal corrections & 3 \\
\hline Marginal notes & 0 \\
\hline Deletions & 1 \\
\hline Erasures & 0 \\
\hline Interlinear corrections & 4 \\
\hline Corrections within the text & 1 \\
\hline
\end{tabular}

On all counts, this scribe has the most accurate hand within the secondary group of MSS. Throughout the entire copying, he made 6 substitutions, 2 omissions, and no additions, transpositions, and non-sense readings. There are only 4 interlinear corrections, 3 marginal corrections, 1 deletion, and 1 correction within the text. At the same time, this MS has limited value for the reconstruction of the initial form of text due to being a direct copy from MS G, and therefore having a tertiary position. 


\section{Scribe of MS K}

\begin{tabular}{|l|l|}
\hline Omissions & $103 / 321$ \\
\hline Additions & $47 / 82 / 2^{\mathrm{R}} / \underline{6}$ \\
\hline Substitutions & $54 / \underline{10}$ \\
\hline Transpositions & 7 \\
\hline Non-sense readings & 6 \\
\hline Marginal corrections & 19 \\
\hline Marginal notes & $16 / 12^{\mathrm{L}}$ \\
\hline Deletions & $5 / 3^{\mathrm{R}}$ \\
\hline Erasures & 0 \\
\hline Interlinear corrections & 16 \\
\hline Corrections within the text & 7 \\
\hline
\end{tabular}

This scribe produced the most corrupted MS of the ten, and it has the last position within the secondary group of MSS on almost all counts. His most common scribal habit has to do with omissions (321 vs $2,36,61,154,154)$, which sometimes involves his failure to copy the middle part of words, and not just their first or last letters. Compared with the number of omissions, he makes far fewer additions ( 82 vs $0,12,12,52,77)$ and substitutions (54 vs $6,18,21,26,51)$. The number of transpositions (7) is second to MS F (13), but higher than in other MSS within the secondary group $(0,0,0,2)$. He introduces the highest number of deliberate changes in the text (16 vs $0,0,1,4,12)$, and writes 16 marginal glosses of which 12 are more than two words long, and several have a clearly theological-polemical purpose (to be discussed in just a little while).

\section{Scribe of MS L}

\begin{tabular}{|l|l|}
\hline Omissions & $16 / 154$ \\
\hline Additions & $3 / 12 / 1^{\mathrm{R}} / \underline{1}$ \\
\hline Substitutions & $26 / \underline{11}$ \\
\hline Transpositions & 0 \\
\hline Non-sense readings & 1 \\
\hline Marginal corrections & 8 \\
\hline
\end{tabular}




\begin{tabular}{|l|l||}
\hline Marginal notes & $16 / 12^{\mathrm{L}}$ \\
\hline Deletions & 1 \\
\hline Erasures & 1 \\
\hline Interlinear corrections & 3 \\
\hline Corrections within the text & 0 \\
\hline
\end{tabular}

This scribe copied directly from MS K, and his most common feature is introducing substitutions (26), of which the most frequent one is changing Бышьнал to Бывшал for $\gamma \varepsilon v \eta \tau \dot{\alpha}$. He has a high number of omitted elements (154), but the estimation of actual cases where he makes omissions is only 16 . The high number of omitted elements has to do with the fact that he makes three rather long omissions $(19,26$, and 39 omitted elements). His third major feature has to do with additions, while the total number of added elements is second in this group (12 vs $0,12,52,77,82)$. He makes no transpositions and uses marginal corrections (8) more frequently than he does interlinear corrections (3). He reproduces the same 16 marginal glosses that are found in MS K, though sometimes arranging them a little bit differently.

\section{Analysis of deliberate/significant changes in the text}

By far the most significant cases of scribal interaction with the text belong to two scribes: one of MS D and another of MS K. In this section, I would like to discuss their scribal habits in a little more detail by looking at those cases where they make deliberate textual changes and add significant marginal comments that illustrate their perceptions of what they copy. I will begin with a few remarks about the MS tradition for each of the two codices and then spend the rest of time examining their scribal habits with special attention to the Second Oration.

\subsection{Scribe of MS D}

The scribe that copied MS D made two colophons with important information for our purposes ${ }^{6}$. In the longer colophon (f. $237^{r}-237^{v}$ ) he calls himself Timofej

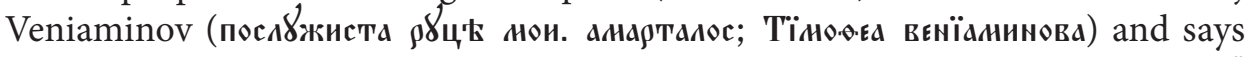
that he produced his MS in Great Novgorod (в то л'Ето здєск в'ъ пюєия'Енитё T⿱ copying the Orations on October $16^{\text {th }}$ in the year 6997 (= 1489) (nисd̂ noc nêtнero

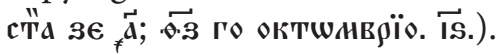

\footnotetext{
${ }^{6}$ For the full text of both colophons, see Oratio II contra Arianos, p. 373-374.
} 
According to the longer colophon, the work of copying was occasioned by the rise of a heresy known in church terminology as the heresy of the Judaizers ${ }^{7}$. Promoted by both clergy and laypeople, this heresy attacked the most fundamental

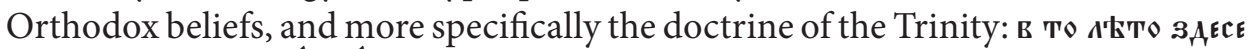

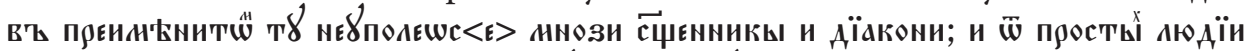

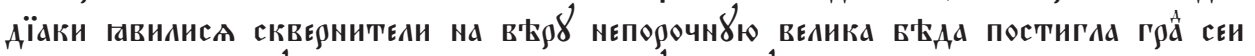

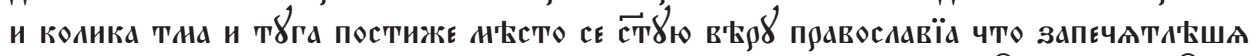

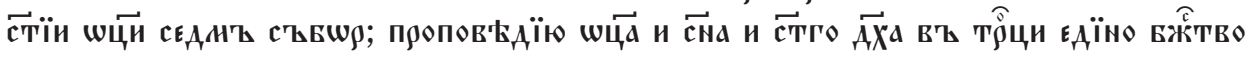
нєразд'Слино. (f. 237v) ${ }^{8}$. This heresy was successfully countered by the Novgoro-

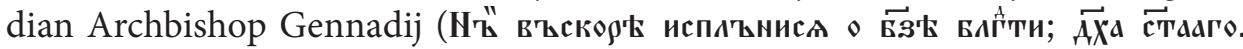

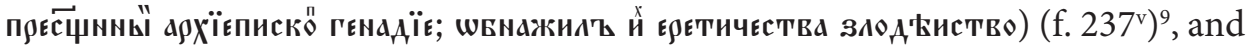
Athanasius' Orations (representing the classical trinitarian doctrine) were clearly designed to support Gennadij's task.

Throughout the MS, we have several marginal notes where Timofej says that he copied from the Old Bulgarian codex: copied from the Bulgarian [book] (<в' во $>\mathbf{л г а р с к о и ~ < с п и и > с а н о , ~ f . ~} 9^{v}$ ), in the old Athanasius it is written like this (в старё

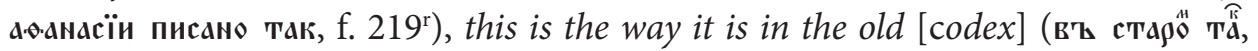
f. $233^{v}$ ). While the scribe is clearly of Russian origin (Novgorod), his handwriting imitates the style of the South-Slavic orthography, in particular the $15^{\text {th }}$-century Serbian polu-ustav with forms of cursive (most likely being influenced by Timofej's teacher - Dominican monk, Veniamin $)^{10}$. Based on the description of the hieromonk Iosif, this MS used to belong to the Iosifo-Volokolamsk Monastery before it was given to the Russian State Library (RGB) where it is kept today ${ }^{11}$.

\footnotetext{
${ }^{7}$ For a thorough treatment of the Judaizers, see А.И. Алексевв, Религиозные движения на Руси последней трети XIV - начала XVI в.: стригольники и жидовствующие, Москва 2012, еsр. p. 385-492.

${ }^{8}$ In that year here in famous Novgorod, many priests and deacons (including those from the simple folks) appeared to profane the pure faith. The town was overtaken by great trouble, and so much darkness and suffering befell this place [and] the holy Orthodox faith, which the holy fathers set down at the seven Councils by preaching the Father and Son and Holy Spirit in the one divine inseparable Trinity (trans. mine).

${ }^{9}$ However, it did not take long for the holy Archbishop Gennadij to expose the wickedness of their heretical teaching after he was filled with God's grace of the Holy Spirit (trans. mine).

${ }^{10}$ On Timofej Veniaminov's handwriting and the influence of his teacher on this scribe, see Л.Д. СЕдельников, К изучению 'Слова кратка' и деятельности доминиканиа Вениамина, ИОРЯС 30 , 1925, р. 223; М.Г. ГАльченко, Второе южнославянское влияние в древнерусской книжности. (Графико-орфографические признаки второго южнославянского влияния и хронология их появления в древнерусских рукописях кониа XIV - первой половины XV вв.), [in:] Книжная культуpa. Книгописание. Надписи на иконах древней Руси, еd. ІDEм, Москва-Санкт-Петербург 2001, p. 325-382, 384-420.

${ }^{11}$ Иосиф (Нieromonк), Опись рукописей, перенесенных из библиотеки Иосифова манастыря в библиотеку Московской духовной академии, Москва 1882, р. 73-74.
} 
The most typical way Timofej changes the text of the Orations is by "Hellenizing" the Slavonic. He does that in two ways. First, he changes the Slavonic words to Greek words or word forms, which he consistently writes in Cyrillic script. The most frequent example is naвı⿻c for "Paul" (e.g. 45.23, 62.30, 62.31). Other cases throughout the MS include

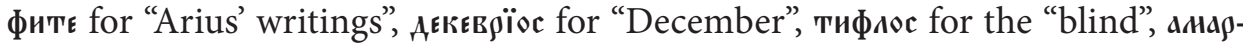
TaAoc for "sinner", TEAOC for the "end", and some others. The second way Timofej Hellenizes the Orations is by adding a number of Greek New Testament quotes written in Cyrillic script (with a few ligatures and Greek letter forms) and placed in the margins alongside the same quotes in the Slavonic text. The longest of such quotes appear on ff. 161 and 165 in the third Oration, and their presence suggests that Timofej made use of a Greek New Testament ${ }^{12}$ and checked Athanasius' citations against it:

\begin{tabular}{|c|c|}
\hline CA III.26, f. $161^{\mathrm{r}}$ & 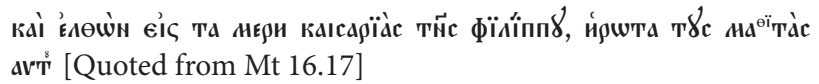 \\
\hline CA III.26, f. $161^{\mathrm{r}}$ & 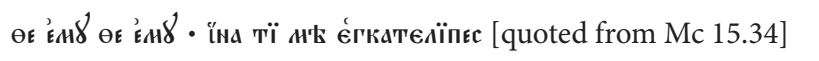 \\
\hline CA III. 32, f. $165^{\mathrm{v}}$ & 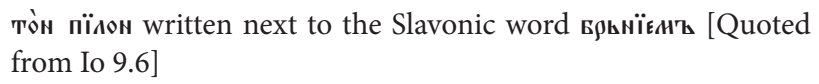 \\
\hline CA III. 32, f. $165^{\mathrm{v}}$ & 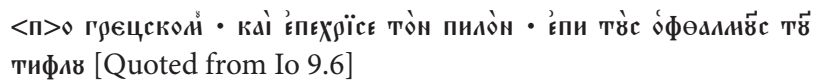 \\
\hline
\end{tabular}

This exotic scribal feature led some scholars ${ }^{13}$ to believe that Timofej had a certain knowledge of Greek, which he probably learned from his teacher Veniamin. In yet another MS (RNB, St. Petersburg, Kirillo-Belozersk 36/41, the 1480s-1490s, ff. 3-246), which appears to be Timofejs Greek workbook, he copied much larger portions of Greek, and based on the numerous mistakes of itacism, declension, and orthography in that workbook, it is generally thought that his knowledge of Greek was fairly elementary ${ }^{14}$. Even then, as Romanchuk notes, Timofei's concrete knowledge of Greek, while crude by our standards, probably impressed his compatriots ${ }^{15}$.

\footnotetext{
${ }^{12}$ Sее Б.Л. Фонкич, Греческо-русские культурные связи в XV-XVII вв. (Греческие рукописи в России), Москва 1977, p. 41. Fonkič suggests that Timofej used a Greek Gospel lectionary, also known as Aprakos.

${ }^{13}$ Seе еsр. Б.Л. Фонкич, Греческо-русские культурные связи..., р. 36-37.

${ }^{14}$ Б.Л. Фонкич, Греческо-русские культурные связи..., р. 40-41.

${ }^{15}$ R. Romanchuk, Once Again on the Greek Workbook of Timofei Veniaminov, Fifteenth-Century Novgorod Monk, [in:] Monastic Traditions. Selected Proceedings of the Fourth International Hilandar Conference. The Ohio State University 1998, ed. C.E. Gribble, P. Matejic, Columbus 2003, p. 286.
} 
Besides the Greek quotes in MS D, Timofej also adds a few Slavonic marginalia and macaronic notes. Some of them are longer (as in the first three examples), while others are shorter (as in the fifth example). All of them suggest that Timofej considered his task of copying the Orations not only in transmitting the text correctly but also in making sure that his readers make the most out of it:

\begin{tabular}{|c|c|}
\hline CA III.44, f. $175^{\mathrm{r}}$ & 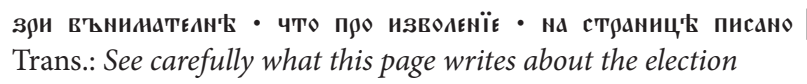 \\
\hline CA III.58, f. $186^{\mathrm{r}}$ & 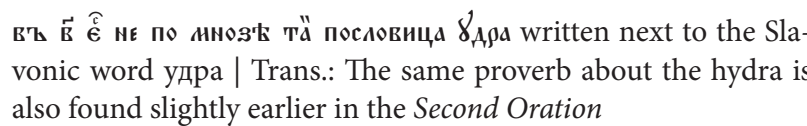 \\
\hline CA IV.1-19, f. $212^{\mathrm{v}}$ & 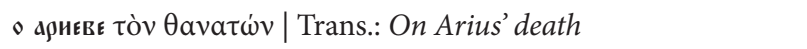 \\
\hline CA IV.1-19, f. 213 & 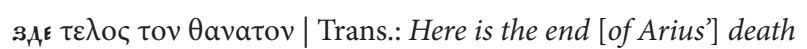 \\
\hline CA III.61, f. $188^{\mathrm{r}}$ & зой | Trans.: See \\
\hline
\end{tabular}

Timofej's desire to play the role of a communicator in addition to being a scribe eventually leads him to make deliberate changes in the text of the Orations. This is clearly seen in his habit of consistently modernizing certain words and phrases in the $10^{\text {th }}$-century Bulgarian text of the Orations in order to make them more comprehensible for his readers in $15^{\text {th }}$-century Russia. The following examples from the second Oration illustrate this feature very well:

\begin{tabular}{|c|c|}
\hline CA II.52.1 & 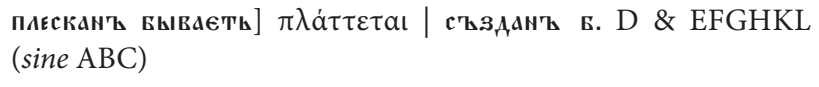 \\
\hline CA II.52.2 & паєсканїА] $\pi \lambda а \sigma \theta \tilde{\eta}$ vаı | зданїа D \& EFGHKL (sine ABC) \\
\hline CA II.52.3 & 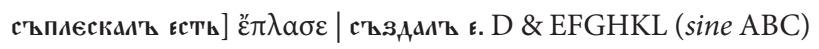 \\
\hline CA II.63.14 & 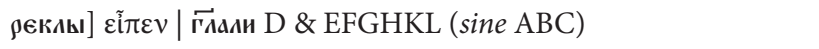 \\
\hline CA II.76.10 & 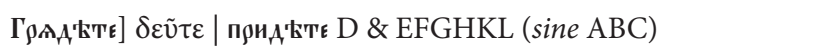 \\
\hline CA II.46.27 & 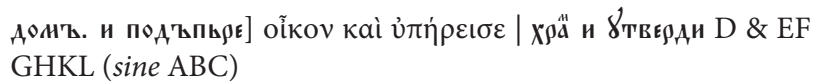 \\
\hline
\end{tabular}

Moreover, Timofej modifies several biblical passages in the Orations to what he believed was a more accurate form of the text. His corrections correspond to the textual forms in the Gennadian Bible (the first complete Slavonic version finished in 1499), and since Timofej belonged to the circle of scribes who compiled 
that Bible during the 1490s, it is very likely that he made use of the biblical MSS in their possession when he copied the Orations in 1489. Furthermore, since the entire project of the Gennadian Bible was a major part of battling the heresy of the Judaizers by making available the complete and most accurate biblical text ${ }^{16}$, it is reasonable to think that Timofej corrected the biblical quotes in the Orations with precisely this agenda in mind. If this is right, then his effort to harmonize the biblical quotes in the Orations with the Gennadian Bible was a way of ensuring that both say the same things, and, therefore, both are equally authoritative. In the second Oration, I have identified four cases where Timofej changed the biblical passages according to the text in the Gennadian Bible. In the following examples, Timofej adds three words (твою, nä and cakAE) and changes one word for another (на for в' $\mathbf{z}$ ):

\begin{tabular}{|c|c|}
\hline CA II.50.25-26 & 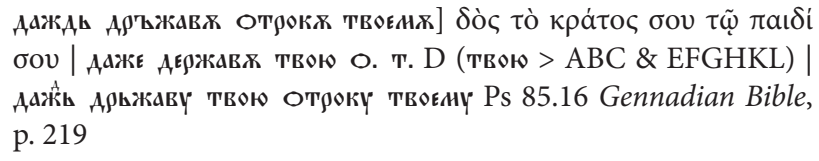 \\
\hline CA II.72.9 & 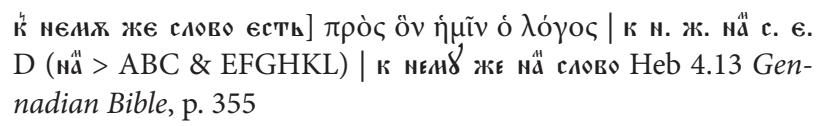 \\
\hline CA II.64.27 & 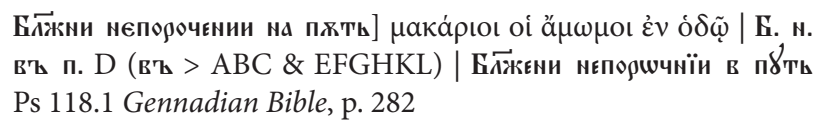 \\
\hline CA II.80.5 & 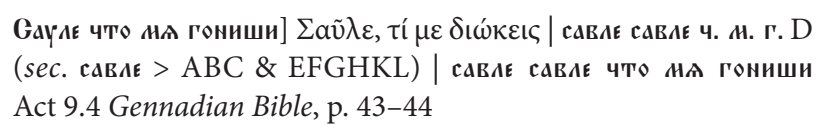 \\
\hline
\end{tabular}

\subsection{Scribe of MS K}

In contrast to what we know about Timofej Veniaminov, there is absolutely no information about the scribe of MS $\mathrm{K}^{17}$. It is possible that he did his work of copying ether in Great Novgorod or Moscow, and his MS was part of the larger collection consisting of twelve volumes and known as the Great Menaion Reader (Velikie Minei Četii). The work on this project was commissioned and assisted by

\footnotetext{
${ }^{16}$ On this, see Е. Сморгунова, Составители и писиы Геннадиевской Библии, [in:] Библия в духовной жизни, истории и культуре России и православного славянского мира. Сборник материалов международной конферениии к 500-летию Геннадиевской Библии, Москва, 21-26 сентября 1999 г., Москва 2001, р. 92-118.

${ }^{17}$ For the description of this MS, see Die Grossen Lesemenäen des Metropoliten Makarij. Uspenskij spisok, vol. I, 1-8 Mai, ed. E. WeIHER et al., Freiburg 2007 [= MLSDV, 51], p. XL-CX.
} 
the Metropolitan of Moscow and all Russia Makarij. The main purpose of creating the Great Menaion Reader was to centralize the cult of the Russian saints and compile all major writings available at the time into twelve volumes according to the twelve months of the church calendar. In 1552 Makarij placed these Menaion in the Cathedral of the Dormition at the Moscow Kremlin, and the text of Athanasius' Orations is contained in the May volume under May 2.

As was mentioned earlier, this scribe produced the most corrupted MS of the ten, introducing the largest number of deliberate/significant changes in the text and adding some glosses that have a clearly theological-polemical purpose. I will discuss both of these features, starting with the second one. The marginal glosses written by this scribe range from several words to a full sentence and can be divided into five groups, each addressing a specific theological issue: (1) Icons; (2) Filioque; (3) Christology; (4) Deification; and (5) Church $^{18}$. Arranged in this way, the theological glosses include the following:

\section{(1) Icons}

\begin{tabular}{|c|c|}
\hline CA II.23, f. $106^{\mathrm{r}}$ & 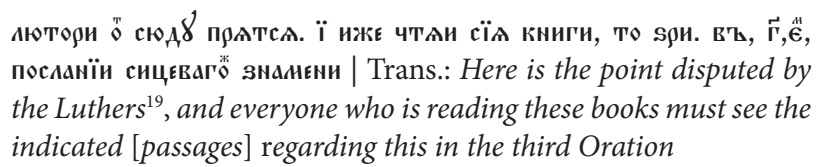 \\
\hline CA III. 4, f. $125^{\mathrm{v}}$ & 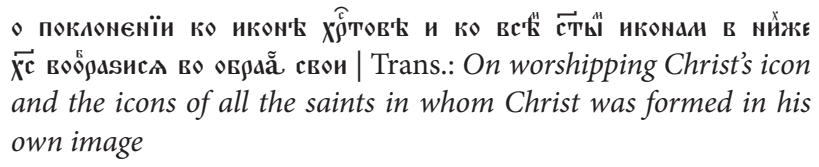 \\
\hline CA III.7, ff. $126^{\mathrm{r}}-126^{\mathrm{v}}$ & на иконоворцы | Trans.: Against the iconoclasts \\
\hline
\end{tabular}

\section{(2) Filioque}

\begin{tabular}{|c|c|}
\hline CA III.14, f. $128^{\mathrm{v}}$ & - подалмїи от сына | Trans.: On the giving from the Son \\
\hline CA III. 24, f. $131^{\mathrm{v}}$ & - п<өдалмї>и <От сына> $\mid$ Trans.: On the giving from the Son \\
\hline
\end{tabular}

18 The same glosses appear in MS L that was directly copied from K: (1) Icons (ff. 337 $7^{\mathrm{v}}-338^{\mathrm{r}} ; 460^{\mathrm{r}}-462^{\mathrm{v}}$; $465^{\mathrm{r}}-467^{\mathrm{r}}$ ); (2) Filioque (ff. 478 $; 496^{\mathrm{r}}$ ); (3) Christology (ff. 459 ${ }^{\mathrm{r}}$; 463 ${ }^{\mathrm{r}}$; 505 ${ }^{\mathrm{v}}$ ); (4) Deification (ff. 487 ${ }^{\mathrm{r}}-$ $487^{\mathrm{v}} ; 495^{\mathrm{r}}$ ); (5) Church (ff. $250^{\mathrm{r}}-251^{\mathrm{r}} ; 119^{\mathrm{v}} ; 424^{\mathrm{r}}-424^{\mathrm{v}}$ ). For a detailed discussion of these glosses, see V.V. Lytvynenko, Athanasius' Orations against the Arians: Theological Glosses in Two Slavonic Manuscripts, ПКШ, 19, p. 77-101.

19 The plural of "Luther" here was used to refer to the Lutheran Christians. Since the word "Luther" was often used as a synonym for "lutyj” (“лютый”), meaning "ferocious", "fierce”, or "cruel”, it functioned as a derogatory name for describing the Protestants. On this, seе Д.И. ЦветАев, Протестанство и протестанты в России до эпохи преобразований, Москва 1890, р. 587. 


\section{(3) Christology}

\begin{tabular}{|c|c|}
\hline CA III.4, f. $125^{\mathrm{r}}$ & - слилмїи | Trans.: On unification \\
\hline CA III.6, f. $126^{\mathrm{r}}$ & $\mathfrak{c} \mathfrak{c} \mid$ Trans.: This \\
\hline CA III.29, f. $133^{\text {r }}$ & нє оуналй но смний | Trans.: Not 'became less' but 'humbled' \\
\hline
\end{tabular}

(4) Deification

\begin{tabular}{||l|l|}
\hline CA III.19, f. 130 & - овожємїи | Trans.: On deification \\
\hline CA III.23, f. 131 & Cross-sign (+) next to the word шБОжєни́ (deification) \\
\hline
\end{tabular}

(5) Church

\begin{tabular}{|c|c|}
\hline$C A$ I. 43, f. $93^{\mathrm{v}}$ & 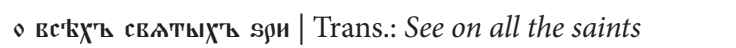 \\
\hline CA II.67, f. $119^{v}$ & О церкви І О Азыцтх| Trans.: On the Church and nations \\
\hline
\end{tabular}

Based on what the scribe writes in these glosses, it is clear that he considers the Orations as a major proof-text concerning the fundamental points of the Orthodox doctrine. His reference to Luther and iconoclasts suggests that his primary opponent was Protestantism, which fits well with what we know about the religious situation in Russia during the 16-17 centuries. The emerging Protestants in that context were coming primarily from the south-western parts of Russia (known as Little Russia that covered most of the territory of modern-day Ukraine), as well as from Poland ${ }^{20}$. Most of them denied a number of distinctively Orthodox doctrines, and the more radical groups of Protestants (the so-called Socinians) $)^{21}$ went as far as to reject Christ's divine nature and the Trinity. Copying the Orations with this polemical agenda in mind allows the scribe to make Athanasius relevant to his own context, and the fact that his glosses were copied again by another scribe around 100 years later (RGB, Moscow, Ovč. F.209, 99, mid- $17^{\text {th }}$ century) shows that his appropriation of Athanasius was taken seriously.

\footnotetext{
${ }^{20}$ The issue of Protestantism in Russia and the Orthodox-Protestant polemic is discussed in many works. See esp. a collection of articles on this topic in Православие Украины и Московской Руси в XVI-XVII веках: Общее и различное, еd. М.В. Дмитриев, Москва 2012.

${ }^{21}$ See e.g. Socinianism and its Role in the Culture of XVI th to XVIII ${ }^{\text {th }}$ Centuries, ed. L. SzczuckI, Warsaw-Lodz 1983.
} 
This situation, however, raises the question as to whether the scribe could have felt it necessary to change the original text of the Orations in order to fit Athanasius to his theological needs. Based on my analysis of the second Oration, the most significant changes that he makes can be divided into those that seem to function as deliberate corrections of the initial text and others that are intended to modernize or re-state certain things a little bit differently. The following examples illustrate the first type of changes:

\begin{tabular}{|c|c|}
\hline CA II.13.2 & 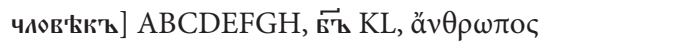 \\
\hline CA II.57.3 & 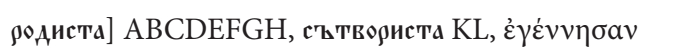 \\
\hline CA II.74.26 & 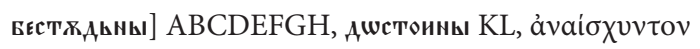 \\
\hline CA II.24.32 & 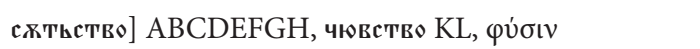 \\
\hline
\end{tabular}

It is hard to say what exactly motivated the scribe to make these changes, but the substituted words are clearly the opposite of what the original text actually states: "man" is changed for "God", "born" for "created", "shameless" for "worthy", and "nature" for "feeling". Moreover, given the importance of the words "born" and "created" in the fourth-century context, to change one word with another implies that instead of being "born" of God the Father, Christ was merely "created" alongside other creatures, which (as a heresy called "Arian") contradicts both Athanasius and the scribe's intention to affirm Christ's divinity in his glosses. The number of such changes is not large, and I suggest that these changes may have to do with the scribe's failure to understand the original meaning of the text or perhaps miscopying it in some places.

The other type of changes can be subdivided into those that substitute entire words with synonyms and those that change only parts of words in order to restate them differently. The former can be illustrated with the following examples:

\begin{tabular}{|c|c|}
\hline CA II.7.6 & 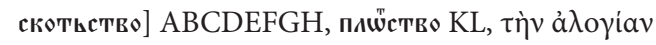 \\
\hline CA II.14.19 & 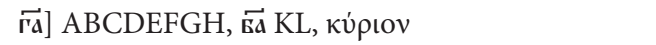 \\
\hline CA II.44.21 & 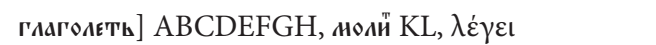 \\
\hline
\end{tabular}

Some examples of the latter include the following: 


\begin{tabular}{|c|c|}
\hline CA II.2.21 & 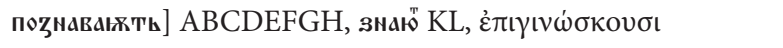 \\
\hline CA II.8.14 & 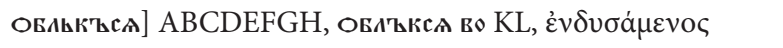 \\
\hline CA II.52.20 & 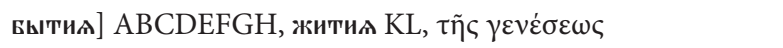 \\
\hline CA II.60.24 & 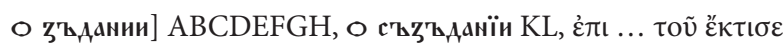 \\
\hline CA II.61.22 & 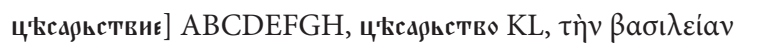 \\
\hline CA II.68.31 & 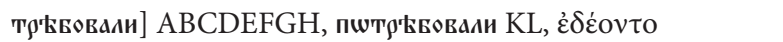 \\
\hline
\end{tabular}

\section{Conclusion}

To summarize my discussion of the scribal habits in the Second Oration, several points can be made in conclusion. First, my classification of the scribal habits according to specific categories has proved to be a helpful instrument for understanding the quality of individual MSS. Thus, for example, the data I have collected has revealed that in many ways the scribes of MSS A \& H produced the most faithful copies of their protographs, while the scribes of MSS D \& K have corrupted theirs the most.

Second, the study of the scribal habits enables us to visualize the strengths and weaknesses in how the scribes went about reproducing the initial text of the Orations. Thus, for example, one's tendency to make frequent omissions does not mean that one tends to introduce additions as often, and vice versa. Our knowledge of these strengths and weaknesses allows us to make better use of the MSS for reconstructing the history of the text and appreciate their individual values.

Third, a clear picture of the scribal practices and attitudes helps to discern the possible patterns in the way some scribes changed the text of the Orations, and perhaps uncover the reasons why they did what they did. Thus, the high number of deliberate/significant changes in MSS D and K connects in some way to the fact that both of them have a clear theological agenda: either to fight the heresy of the Judaizers (scribe of MS D), or to polemicize with growing Protestantism (scribe of MS K). Consequently, their theological concerns and local contexts significantly affected the way they read and copied the Orations.

\section{Appendix}

The table in this Appendix is designed to complement the ten shorter tables by indicating all individual cases for each of the eleven scribal categories in our MSS. Before presenting this table, however, I need to provide some explanation on how 
to use it. First of all, the data contained here is based on my analysis of Athanasius's Second Oration against the Arians ${ }^{22}$. Second, the scribal habits in this table are classified according to eleven categories: (1) omissions, (2) additions, (3) substitutions, (4) transpositions, (5) non-sense readings, (6) marginal corrections, (7) marginal notes, (8) deletions, (9) erasures, (10) interlinear corrections, and (11) corrections within the text. Third, for each of these categories or scribal features the table offers two types of statistics that describe each of the ten MSS: the total estimates placed on the top of the table and highlighted in bold, and the singular estimates that take up most of the space in the table under the bold numbers. The numbers in both of these sections need some further explanation.

To begin with the top section, the data here consists of one or more numbers. The first number gives the total sum of occurrences for a particular scribal feature, and any other numbers that follow are separated by a slash and mean one of two things. First, in the section with omissions and additions, the second number after the slash means the total estimate of omitted and added letters. Thus, for example, if the table shows 51/96 of omissions and 23/166 of additions, it means that the scribe made 51 cases of omission resulting in 96 omitted letters, and 23 cases of addition resulting in 166 added letters. To have this kind of statistics allows us to see how many elements the scribe omits and adds, as well as how often he does it. Second, there are three more types of numbers that need to be understood according to the following indicators next to them: ${ }^{\mathrm{R}}$, ${ }^{\mathrm{L}}$, underlining. Here, letter ${ }^{\mathrm{R}}$ means a case of redundancy, letter ${ }^{\mathrm{L}}$ means a marginal note that is two or more letters long, and any underlined number means a deliberate/ significant change in the text. Thus, again, if the table shows $23 / 166 / 6^{\mathrm{R}} / 1$ of additions, it means that the scribe made 23 cases of addition resulting in 166 added letters, and out of 23 cases of addition there are $6^{\mathrm{R}}$ cases where he added a redundant letter or syllable, and there is $\underline{1}$ case where he made a deliberate or significant addition in the text. Similarly, if the table shows $16 / 12^{\mathrm{L}}$ cases of marginal notes, it means that the scribe made 16 marginal notes, of which $12^{\mathrm{L}}$ cases are notes two or more letters long.

Finally, in the section with singular estimates, I indicate the chapter and line from my edition of the Second Oration for every single occurrence. For omissions and additions, I also add an indexed number to show how many letters are omitted or added in each case. For instance, if the table shows $5.2^{3}$ for omissions, it means that the scribe omitted 3 letters in the Second Oration, chapter 5, line 2. Or to give another example, if the number shows $51.24^{83 \mathrm{R}}$ for additions, it means that the scribe mistakenly copied 83 letters twice in the Second Oration, chapter 51, line 24. If there is more than one omission, addition or some other scribal feature in the same place, I indicate it in the brackets as follows: $5 \cdot 2^{3}(2)$.

${ }^{22}$ Oratio II contra Arianos. 
OMISSIONS

\begin{tabular}{|c|c|c|c|c|c|c|c|c|c|}
\hline A & B & C & D & E & $\mathrm{F}$ & G & $\mathrm{H}$ & $\mathrm{K}$ & $\mathrm{L}$ \\
\hline $51 / 96$ & $138 / 455$ & $99 / 211 / \underline{1}$ & $119 / 273 / \underline{3}$ & $35 / 61 / \underline{1}$ & $61 / 154 / \underline{1}$ & $21 / 36$ & $1 / 2$ & $103 / 321$ & $16 / 154$ \\
\hline $1.39^{1}$ & $1.18^{2}$ & $1.30^{1}$ & $1.3^{1}$ & $7.32^{1}$ & $3.31^{1}$ & $4.19^{2}$ & $1.3^{2}$ & $1.4^{1}$ & $2.21^{2}$ \\
\hline $2.24^{1}$ & $1.26^{2}$ & $2.7^{3}$ & $4.42^{2}$ & $8.3^{1}$ & $3.33^{2}$ & $4.37^{2}$ & & $1.15^{2}$ & $5.19^{1}$ \\
\hline $3.8^{1}$ & $2.11^{1}$ & $2.16^{2}$ & $5.14^{2}$ & $11.6^{1}$ & $5.2^{3}$ & $5.4^{1}$ & & $1.31^{2}$ & $13.18^{39}$ \\
\hline $5.1^{2}$ & $2.25^{1}$ & $2.21^{2}$ & $7.17^{2}$ & $12.14^{2}$ & $6.3^{2}$ & $9.10^{2}$ & & $2.20^{4}$ & $14.6^{2}$ \\
\hline $7.20^{2}$ & $2.34^{1}$ & $3.16^{1}$ & $7.25^{2}$ & $12.17^{2}$ & $6.8^{2}$ & $19.3^{2}$ & & $3.8^{3}$ & $16.28^{2}$ \\
\hline $7.36^{2}$ & $2.39^{1}$ & $4.19^{1}$ & $8.18^{1}$ & $12.28^{2}(2)$ & $6.14^{2}$ & $19.4^{2}$ & & $3.13^{2}$ & $16.31^{10}$ \\
\hline $8.7^{2}$ & $3.13^{1}$ & $4.43^{1}$ & $10.33^{2}$ & $\underline{14.19}^{2}$ & $7.18^{3}$ & $23.7^{2}$ & & $3.19^{3}$ & $16.32^{1}$ \\
\hline $8.15^{1}$ & $4.5^{3}$ & $4.45^{2}$ & $12.21^{4}$ & $15.2^{1}$ & $8.5^{5}$ & $23.15^{2}$ & & $4.9^{2}$ & $16.47^{12}$ \\
\hline $9.4^{2}$ & $4.10^{1}$ & $5.4^{1}$ & $13.11^{11}$ & $16.20^{2}$ & $9.16^{2}$ & $24.8^{3}$ & & $6.13^{4}$ & $20.25^{2}$ \\
\hline $10.15^{5}$ & $4.30^{1}$ & $6.19^{1}$ & $13.26^{1}$ & $22.6^{1}$ & $11.32^{4}$ & $37.17^{2}$ & & $8.11^{2}$ & $22.30^{19}$ \\
\hline $11.32^{4}$ & $6.2^{35}$ & $7.5^{2}$ & $13.28^{1}$ & $24.1^{1}$ & $12.3^{2}$ & $38.22^{2}$ & & $9.5^{2}$ & $24.10^{6}$ \\
\hline $16.3^{2}$ & $6.6^{2}$ & $7.21^{1}$ & $14.4^{8}$ & $25.24^{1}$ & $12.11^{1}$ & $40.8^{1}$ & & $9.9^{1}$ & $25.1^{2}$ \\
\hline $16.18^{2}$ & $6.7^{1}$ & $7.28^{1}$ & $14.15^{6}$ & $25.25^{2}$ & $14.19^{10}$ & $43.1^{1}$ & & $10.7^{1}$ & $37.13^{7}$ \\
\hline $17.8^{2}$ & $6.15^{18}$ & $8.3^{1}$ & $14.18^{3}$ & $27.2^{1}$ & $16.39^{2}$ & $51.29^{2}$ & & $10.17^{1}$ & $47.21^{26}$ \\
\hline $19.11^{1}$ & $7.15^{2}$ & $8.25^{2}$ & $15.2^{6}$ & $28.14^{3}$ & $19.22^{1}$ & $53.9^{1}$ & & $16.17^{2}$ & $47.23^{2}$ \\
\hline $19.28^{3}$ & $7.21^{1}$ & $10.19^{2}$ & $16.41^{2}$ & $29.15^{2}$ & $19.37^{3}$ & $53.27^{1}$ & & $16.30^{1}$ & $56.11^{21}$ \\
\hline $19.29^{2}$ & $7.27^{2}$ & $10.33^{2}$ & $17.6^{3}$ & $30.22^{2}$ & $20.21^{1}$ & $54.20^{1}$ & & $17.4^{2}$ & \\
\hline $23.37^{1}$ & $7.35^{2}$ & $12.21^{2}$ & $17.10^{1}$ & $30.35^{1}$ & $23.17^{2}$ & $57.10^{1}$ & & $17.8^{2}$ & \\
\hline $24.32^{2}$ & $10.25^{1}$ & $12.28^{2}$ & $19.28^{1}$ & $32.17^{1}$ & $24.1^{2}$ & $58.27^{2}$ & & $19.3^{2}$ & \\
\hline $25.31^{2}$ & $10.28^{2}$ & $13.26^{1}$ & $21.17^{2}$ & $36.17^{2}$ & $24.7^{8}$ & $63.17^{2}$ & & $20.29^{3}$ & \\
\hline $27.5^{2}$ & $11.14^{1}$ & ${\underline{16.1^{2}}}^{2}$ & $22.11^{1}$ & $40.23^{1}$ & $25.10^{2}$ & $71.14^{2}$ & & $21.3^{1}$ & \\
\hline $28.22^{2}$ & $11.34^{3}$ & $16.26^{1}$ & $22.18^{2}$ & $46.2^{2}$ & $25.25^{2}$ & & & $22.2^{3}$ & \\
\hline $33.7^{2}$ & $12.2^{1}$ & $16.45^{2}$ & $22.24^{2}$ & $49.27^{2}$ & $25.26^{2}$ & & & $22.25^{2}$ & \\
\hline $33.13^{1}$ & $12.4^{2}$ & $17.24^{3}$ & $22.36^{1}$ & $56.3^{1}$ & $26.12^{2}$ & & & $24.29^{2}$ & \\
\hline $36.18^{1}$ & $12.6^{1}$ & $18.17^{1}$ & $23.12^{2}$ & $56.5^{1}$ & $26.21^{4}$ & & & $25.29^{1}$ & \\
\hline $37.29^{1}$ & $12.20^{4}$ & $19.7^{1}$ & $23.37^{1}$ & $58.20^{6}$ & $27.14^{2}$ & & & $26.1^{1}$ & \\
\hline $38.8^{2}$ & $13.16^{1}$ & $19.17^{2}$ & $25.4^{1}$ & $58.27^{1}$ & $27.22^{1}$ & & & $27.6^{1}$ & \\
\hline $42.5^{4}$ & $13.26^{1}$ & $19.33^{2}$ & $27.19^{4}$ & $60.33^{4}$ & $27.26^{1}$ & & & $28.1^{1}$ & \\
\hline $42.27^{2}$ & $14.3^{1}$ & $19.35^{1}$ & $27.37^{2}$ & $62.26^{4}$ & $27.38^{1}$ & & & $28.6^{2}$ & \\
\hline $43.9^{1}$ & $14.11^{1}$ & $20.4^{1}$ & $28.11^{2}$ & $65.3^{2}$ & $30.18^{5}$ & & & $28.29^{21}$ & \\
\hline $43.16^{2}$ & $14.11^{2}$ & $20.26^{1}$ & $29.1^{2}$ & $67.22^{1}$ & $31.26^{1}$ & & & $29.2^{4}$ & \\
\hline $45.4^{1}$ & $14.12^{4}$ & $21.6^{1}$ & $29.9^{2}$ & $71.3^{2}$ & $31.29^{2}$ & & & $29.9^{2}$ & \\
\hline $48.19^{2}$ & $14.20^{3}$ & $21.10^{2}$ & $30.4^{2}$ & $76.22^{1}$ & $32.22^{2}$ & & & $29.22^{1}$ & \\
\hline $49.10^{1}$ & $14.22^{1}$ & $21.14^{1}$ & $31.9^{2}$ & $80.13^{1}$ & $32.35^{1}$ & & & $30.1^{2}$ & \\
\hline $50.8^{1}$ & $15.12^{3}$ & $21.24^{2}$ & $31.10^{2}$ & $82.2^{1}$ & $33.13^{1}$ & & & $30.5^{16}$ & \\
\hline $53.23^{1}$ & $16.28^{2}$ & $22.4^{1}$ & $31.14^{2}$ & & $33.29^{1}$ & & & $30.23^{2}$ & \\
\hline $59.33^{1}$ & $16.30^{2}$ & $22.6^{1}$ & $31.25^{1}$ & & $35.1^{2}$ & & & $30.29^{2}$ & \\
\hline $62.7^{1}$ & $16.36^{2}$ & $22.30^{19}$ & $32.10^{2}$ & & $36.11^{2}$ & & & $31.1^{2}$ & \\
\hline $62.23^{9}$ & $16.45^{2}$ & $23.23^{1}$ & $35.7^{2}$ & & $36.19^{2}$ & & & $31.29^{23}$ & \\
\hline $63.14^{1}$ & $17.3^{2}$ & $23.39^{3}$ & $35.8^{3}$ & & $38.13^{2}$ & & & $32.14^{2}$ & \\
\hline $63.32^{2}$ & $17.8^{17}$ & $24.29^{2}$ & $36.7^{1}$ & & $38.27^{2}$ & & & $35.17^{1}$ & \\
\hline $68.33^{1}$ & $18.21^{2}$ & $25.1^{2}$ & $36.18^{2}$ & & $42.28^{2}$ & & & $36.19^{4}$ & \\
\hline $70.11^{2}$ & $18.28^{4}$ & $27.3^{11}$ & $41.20^{12}$ & & $44.30^{2}$ & & & $37.7^{2}$ & \\
\hline
\end{tabular}


OMISSIONS (cont.)

\begin{tabular}{|c|c|c|c|c|c|c|c|c|c|}
\hline A & B & $\mathrm{C}$ & D & $\mathrm{E}$ & $\mathrm{F}$ & G & $\mathrm{H}$ & K & $\mathrm{L}$ \\
\hline $51 / 96$ & $138 / 455$ & $99 / 211 / 1$ & $119 / 273 / \underline{3}$ & $35 / 61 / 1$ & $61 / 154 / 1$ & $21 / 36$ & $1 / 2$ & $103 / 321$ & $16 / 154$ \\
\hline $70.20^{3}$ & $18.29^{3}$ & $27.12^{3}$ & $41.22^{2}$ & & $45.2^{4}$ & & & $37.20^{4}$ & \\
\hline $70.25^{1}$ & $19.34^{2}$ & $29.5^{5}$ & $42.7^{2}$ & & $50.2^{1}$ & & & $39.3^{3}$ & \\
\hline $71.35^{2}$ & $22.27^{2}$ & $30.5^{2}$ & $42.15^{1}$ & & $50.32^{1}$ & & & $39.21^{2}$ & \\
\hline $75.14^{1}$ & $22.35^{34}$ & $32.18^{2}$ & $43.9^{2}$ & & $52.11^{13}$ & & & $39.30^{2}$ & \\
\hline $75.19^{2}$ & $23.11^{2}$ & $32.25^{2}$ & $43.43^{1}$ & & $54.6^{1}$ & & & $41.15^{6}$ & \\
\hline $76.3^{1}$ & $23.30^{4}$ & $33.6^{1}$ & $44.14^{1}$ & & $54.15^{2}$ & & & $41.35^{1}$ & \\
\hline $76.12^{1}$ & $23.32^{6}$ & $35.24^{2}$ & $45.11^{1}$ & & $55.6^{4}$ & & & $42.3^{2}$ & \\
\hline $81.34^{2}$ & $23.36^{3}$ & $37.35^{1}$ & $45.21^{1}$ & & $55.20^{6}$ & & & $43.12^{2}$ & \\
\hline & $27.3^{11}$ & $40.7^{4}$ & $46.14^{1}$ & & $55.35^{2}$ & & & $43.26^{1}$ & \\
\hline & $27.35^{2}$ & $40.26^{2}$ & $46.36^{1}$ & & $56.13^{2}$ & & & $43.31^{2}$ & \\
\hline & $30.24^{2}$ & $41.23^{2}$ & $47.18^{2}$ & & $56.15^{2}$ & & & $44.8^{3}$ & \\
\hline & $30.26^{2}$ & $43.35^{1}$ & $48.20^{2}$ & & $58.17^{2}$ & & & $44.16^{2}$ & \\
\hline & $30.29^{2}$ & $44.16^{2}$ & $48.27^{2}$ & & $58.32^{2}$ & & & $45.3^{2}$ & \\
\hline & $30.30^{2}$ & $44.30^{2}$ & $48.28^{1}$ & & $63.16^{2}$ & & & $45.13^{1}$ & \\
\hline & $31.2^{2}$ & $44.30^{1}$ & $49.7^{2}$ & & $65.6^{2}$ & & & $45.15^{4}$ & \\
\hline & $31.5^{1}$ & $46.7^{2}$ & ${\underline{50.13^{2}}}^{2}$ & & $66.30^{2}$ & & & $49.9^{6}$ & \\
\hline & $31.13^{1}$ & $46.21^{1}$ & ${\overline{50.14^{2}}}^{2}$ & & $\underline{67.13}^{2}$ & & & $49.14^{4}$ & \\
\hline & $31.21^{2}$ & $47.17^{2}$ & $52.16^{2}$ & & $77.8^{1}$ & & & $51.13^{21}$ & \\
\hline & $32.27^{1}$ & $47.23^{2}$ & $52.34^{2}$ & & $80.17^{1}$ & & & $51.35^{4}$ & \\
\hline & $34.3^{2}$ & $48.2^{2}$ & $53.33^{2}$ & & & & & $52.21^{3}$ & \\
\hline & $34.14^{1}$ & $48.4^{2}$ & $54.9^{1}$ & & & & & $52.28^{3}$ & \\
\hline & $35.8^{2}$ & $48.19^{2}$ & $54.9^{2}$ & & & & & $54.22^{3}$ & \\
\hline & $35.15^{2}$ & $48.30^{2}$ & $54.16^{2}$ & & & & & $55.22^{1}$ & \\
\hline & $37.6^{1}$ & $50.13^{1}$ & $54.23^{1}$ & & & & & $55.31^{1}$ & \\
\hline & $37.9^{2}$ & $51.3^{2}$ & $55.11^{1}$ & & & & & $55.37^{1}$ & \\
\hline & $37.12^{1}$ & $51.22^{2}$ & $55.36^{2}$ & & & & & $56.6^{4}$ & \\
\hline & $37.28^{3}$ & $53.3^{1}$ & $56.10^{2}$ & & & & & $56.16^{1}$ & \\
\hline & $38.15^{19}$ & $53.27^{1}$ & $56.19^{4}$ & & & & & $57.16^{1}$ & \\
\hline & $38.28^{2}$ & $54.5^{2}$ & $56.31^{1}$ & & & & & $58.19^{2}$ & \\
\hline & $39.9^{2}$ & $54.6^{1}$ & $57.4^{4}$ & & & & & $59.13^{4}$ & \\
\hline & $41.27^{2}$ & $54.14^{1}$ & $57.22^{4}$ & & & & & $59.20^{2}$ & \\
\hline & $43.18^{6}$ & $55.18^{1}$ & $58.3^{1}$ & & & & & $59.30^{2}$ & \\
\hline & $43.18^{1}$ & $55.39^{2}$ & $59.12^{4}$ & & & & & $59.35^{4}$ & \\
\hline & $44.2^{2}$ & $56.13^{1}$ & $59.22^{2}$ & & & & & $59.39^{3}$ & \\
\hline & $45.2^{1}$ & $56.24^{2}$ & $59.40^{2}$ & & & & & $60.4^{1}$ & \\
\hline & $45.18^{3}$ & $57.7^{2}$ & $60.27^{5}$ & & & & & $60.5^{2}$ & \\
\hline & $46.36^{2}$ & $57.15^{2}$ & $62.4^{2}$ & & & & & $60.27^{5}$ & \\
\hline & $47.9^{2}$ & $57.15^{2}$ & $62.6^{2}$ & & & & & $63.33^{1}$ & \\
\hline & $47.11^{2}$ & $58.21^{2}$ & $62.20^{1}$ & & & & & $66.7^{2}$ & \\
\hline & $49.6^{2}$ & $62.6^{1}$ & $62.30^{4}$ & & & & & $67.17^{6}$ & \\
\hline & $49.26^{1}$ & $64.11^{1}$ & $62.30^{3}$ & & & & & $68.28^{2}$ & \\
\hline & $50.18^{1}$ & $\underline{66.6^{2}}$ & $63.10^{5}$ & & & & & $69.7^{2}$ & \\
\hline & $50.21^{14}$ & $67.34^{2}$ & $63.20^{4}$ & & & & & $70.26^{2}$ & \\
\hline & $50.31^{2}$ & $68.6^{2}$ & $64.14^{2}$ & & & & & $70.26^{6}$ & \\
\hline
\end{tabular}


OMISSIONS (cont.)

\begin{tabular}{|c|c|c|c|c|c|c|c|c|c|}
\hline A & B & C & D & E & F & G & $\mathrm{H}$ & K & $\mathrm{L}$ \\
\hline $51 / 96$ & $138 / 455$ & $99 / 211 / 1$ & $119 / 273 / \underline{3}$ & $35 / 61 / 1$ & $61 / 154 / 1$ & $21 / 36$ & $1 / 2$ & $103 / 321$ & $16 / 154$ \\
\hline & $51.1^{1}$ & $68.8^{1}$ & $64.21^{2}$ & & & & & $71.12^{2}$ & \\
\hline & $51.29^{3}$ & $68.15^{1}$ & $64.29^{2}$ & & & & & $71.18^{4}$ & \\
\hline & $51.37^{1}$ & $70.15^{2}$ & $64.33^{1}$ & & & & & $71.19^{1}$ & \\
\hline & $52.25^{1}$ & $71.3^{2}$ & $65.1^{7}$ & & & & & $73.7^{7}$ & \\
\hline & $53.15^{2}$ & $72.4^{1}$ & $65.3^{2}$ & & & & & $74.5^{2}$ & \\
\hline & $55.25^{2}$ & $73.20^{20}$ & $66.4^{1}$ & & & & & $75.13^{1}$ & \\
\hline & $56.17^{1}$ & $74.11^{1}$ & $66.4^{4}$ & & & & & $76.2^{4}$ & \\
\hline & $59.25^{2}$ & $74.11^{1}$ & $67.6^{4}$ & & & & & $76.4^{4}$ & \\
\hline & $59.37^{6}$ & $75.31^{2}$ & $67.8^{2}$ & & & & & $76.12^{1}$ & \\
\hline & $60.28^{2}$ & $76.22^{2}$ & ${\underline{67.13^{2}}}^{2}$ & & & & & $77.4^{2}$ & \\
\hline & $61.2^{1}$ & $80.24^{2}$ & $67.17^{2}$ & & & & & $78.6^{3}$ & \\
\hline & $61.2^{2}$ & $81.15^{2}$ & $68.17^{1}$ & & & & & $78.8^{1}$ & \\
\hline & $61.22^{2}$ & & $70.2^{2}$ & & & & & $79.33^{7}$ & \\
\hline & $62.1^{7}$ & & $70.2^{1}$ & & & & & $82.5^{2}$ & \\
\hline & $62.22^{2}$ & & $72.5^{2}$ & & & & & $82.7^{2}$ & \\
\hline & $63.7^{2}$ & & $72.14^{2}$ & & & & & $82.12^{1}$ & \\
\hline & $63.24^{2}$ & & $72.27^{1}$ & & & & & & \\
\hline & $64.6^{1}$ & & $72.32^{1}$ & & & & & & \\
\hline & $64.17^{2}$ & & $74.1^{2}$ & & & & & & \\
\hline & $64.18^{1}$ & & $76.16^{1}$ & & & & & & \\
\hline & $64.21^{2}$ & & $76.19^{2}$ & & & & & & \\
\hline & $65.1^{1}$ & & $77.2^{1}$ & & & & & & \\
\hline & $65.8^{2}$ & & $77.25^{2}$ & & & & & & \\
\hline & $65.8^{2}$ & & $78.11^{2}$ & & & & & & \\
\hline & $66.3^{1}$ & & $78.11^{3}$ & & & & & & \\
\hline & $66.15^{1}$ & & $79.12^{2}$ & & & & & & \\
\hline & $66.22^{2}$ & & $79.16^{1}$ & & & & & & \\
\hline & $67.9^{1}$ & & $80.7^{4}$ & & & & & & \\
\hline & $67.19^{1}$ & & $80.8^{4}$ & & & & & & \\
\hline & $67.23^{3}$ & & $81.33^{1}$ & & & & & & \\
\hline & $68.4^{1}$ & & $82.4^{1}$ & & & & & & \\
\hline & $68.16^{14}$ & & $82.25^{1}$ & & & & & & \\
\hline & $68.32^{2}$ & & & & & & & & \\
\hline & $69.4^{13}$ & & & & & & & & \\
\hline & $69.17^{2}$ & & & & & & & & \\
\hline & $70.1^{2}$ & & & & & & & & \\
\hline & $72.22^{2}$ & & & & & & & & \\
\hline & $72.22^{1}$ & & & & & & & & \\
\hline & $72.26^{2}$ & & & & & & & & \\
\hline & $73.9^{2}$ & & & & & & & & \\
\hline & $74.22^{9}$ & & & & & & & & \\
\hline & $74.27^{1}$ & & & & & & & & \\
\hline & $75.13^{11}$ & & & & & & & & \\
\hline & $75.15^{3}$ & & & & & & & & \\
\hline
\end{tabular}


OMISSIONS (cont.)

\begin{tabular}{|c|c|c|c|c|c|c|c|c|c|}
\hline $\mathrm{A}$ & B & $\mathrm{C}$ & $\mathrm{D}$ & $\mathrm{E}$ & $\mathrm{F}$ & $\mathrm{G}$ & $\mathrm{H}$ & $\mathrm{K}$ & $\mathrm{L}$ \\
\hline $51 / 96$ & $138 / 455$ & $99 / 211 / \underline{1}$ & $119 / 273 / \underline{3}$ & $35 / 61 / \underline{1}$ & $61 / 154 / \underline{1}$ & $21 / 36$ & $1 / 2$ & $103 / 321$ & $16 / 154$ \\
\hline & $\begin{array}{l}76.19^{1} \\
76.32^{1} \\
76.33^{1} \\
78.24^{1} \\
78.29^{1} \\
81.4^{14} \\
82.12^{2}\end{array}$ & & & & & & & & \\
\hline
\end{tabular}

ADDITIONS

\begin{tabular}{|c|c|c|c|c|c|c|c|c|c|}
\hline A & B & $\mathrm{C}$ & $\mathrm{D}$ & $\mathrm{E}$ & F & G & $\mathrm{H}$ & K & $\mathrm{L}$ \\
\hline $23 / 166 / 6^{\mathrm{R}} / \underline{1}$ & $102 / 509 / 7^{\mathrm{R}} / \underline{3}$ & $39 / 164 / 2^{\mathrm{R}}$ & $63 / 128 / 3^{\mathrm{R}} / 12$ & $18 / 52$ & $48 / 77 / 1^{\mathrm{R}}$ & $7 / 12 / 2^{\mathrm{R}}$ & 0 & $47 / 82 / 2^{\mathrm{R}} / \underline{6}$ & $3 / 12 / 1^{\mathrm{R}} / \underline{1}$ \\
\hline $1.12^{2}$ & $1.1^{1}$ & $1.9^{1}$ & $1.2^{1}$ & $5.4^{4 \mathrm{R}}$ & $1.6^{2}$ & $3.9^{1}$ & & $1.30^{2}$ & $3.10^{7 \mathrm{R}}$ \\
\hline $8.34^{1}$ & $1.25^{1}$ & $4.8^{4}$ & $1.30^{1}$ & $12.6^{2}$ & $1.44^{2}$ & $11.21^{2}$ & & $2.35^{2}$ & $51.20^{1}$ \\
\hline${\underline{8.38^{3}}}^{3}$ & $1.44^{2}$ & $6.1^{1}$ & $3.16^{2}$ & $14.29^{3}$ & $3.9^{1}$ & $12.1^{2}$ & & $3.6^{2}$ & ${\underline{58.20^{4}}}^{2}$ \\
\hline $9.31^{1}$ & $2.13^{1}$ & $6.25^{1}$ & $5.20^{2}$ & $16.18^{2}$ & $4.27^{1}$ & $34.7^{2}$ & & $7.34^{2}$ & \\
\hline $16.27^{2 \mathrm{R}}$ & $3.3^{2}$ & $6.26^{5}$ & $5.28^{2}$ & $17.21^{1}$ & $5.27^{2}$ & $36.31^{1}$ & & $\underline{8.14}^{2}$ & \\
\hline $26.11^{2}$ & $3.9^{1}$ & $6.29^{1}$ & $6.2^{2}$ & $18.6^{2}$ & $7.9^{2}(2)$ & $79.9^{2 \mathrm{R}}$ & & $9.4^{1}$ & \\
\hline $29.15^{49 R}$ & $3.22^{2}$ & $8.24^{1}$ & $7.1^{3}$ & $24.10^{1}$ & $7.23^{2}$ & $80.36^{2 \mathrm{R}}$ & & $11.9^{2}$ & \\
\hline $31.16^{2}$ & $6.11^{2}$ & $8.34^{1}$ & $\underline{8.29}^{3}$ & $27.21^{1}$ & $8.5^{2}$ & & & ${\underline{11.26^{1}}}^{1}$ & \\
\hline $31.29^{2}$ & $7.3^{1}$ & $10.10^{1}$ & $8.37^{2}$ & $36.15^{2}$ & $8.10^{1}$ & & & $13.2^{1}$ & \\
\hline $40.26^{2}$ & $7.7^{2 \mathrm{R}}$ & $11.25^{4}$ & $9.14^{1}$ & $38.24^{1}$ & $8.29^{1}$ & & & $14.3^{1}$ & \\
\hline $44.32^{1}$ & $8.29^{3}$ & $14.11^{4}$ & $9.20^{1}$ & $39.18^{2 \mathrm{R}}$ & $9.7^{2 \mathrm{R}}$ & & & $14.40^{1}$ & \\
\hline $48.4^{1}$ & $9.8^{1}$ & $14.17^{2}$ & $10.12^{2}$ & $52.26^{2}$ & $10.34^{1}$ & & & $17.15^{1}$ & \\
\hline $49.25^{1}$ & $9.13^{2}$ & $16.57^{1}$ & $10.14^{2}$ & $55.12^{1}$ & $11.6^{1}$ & & & $22.14^{2}$ & \\
\hline $51.24^{83 \mathrm{R}}$ & $10.12^{2}$ & $17.25^{2}$ & $11.25^{2}$ & $55.26^{1}$ & $12.6^{1}$ & & & $25.12^{2}$ & \\
\hline $54.26^{1}$ & $10.34^{1}$ & $18.34^{1}$ & $11.29^{2}$ & $57.3^{13 R}$ & $14.4^{2}$ & & & $25.22^{1}$ & \\
\hline $59.25^{2 \mathrm{R}}$ & $12.7^{1}$ & $24.18^{1}$ & ${\underline{15.3^{2}}}^{2}$ & $59.31^{1}$ & $14.41^{1}$ & & & $27.9^{2}$ & \\
\hline $60.1^{1 \mathrm{R}}$ & $12.13^{2}$ & $28.24^{1}$ & $16.2^{2}$ & $78.29^{6 \mathrm{R}}$ & $16.17^{2}$ & & & $31.37^{1}$ & \\
\hline $67.22^{2 \mathrm{R}}$ & $12.13^{1}$ & $32.27^{2}$ & $16.10^{1}$ & $80.10^{7 \mathrm{R}}$ & $17.5^{2}$ & & & $32.39^{2}$ & \\
\hline $72.23^{2 \mathrm{R}}$ & $12.26^{2}$ & $37.24^{1}$ & $16.27^{1}$ & & $18.6^{3}$ & & & $33.27^{1}$ & \\
\hline $75.28^{1}$ & $14.14^{1}$ & $39.3^{9 \mathrm{R}}$ & $18.6^{1}$ & & $19.27^{2}$ & & & $35.8^{1}$ & \\
\hline $79.15^{2}$ & $14.28^{1}$ & $39.4^{91 \mathrm{R}}$ & $\underline{19.26^{3}}$ & & $21.1^{2}$ & & & $35.19^{3}$ & \\
\hline $79.33^{2}$ & $16.24^{1}$ & $41.43^{1}$ & $19.27^{3}$ & & $21.16^{1}$ & & & $38.22^{2}$ & \\
\hline $81.26^{1}$ & $16.27^{2}$ & $43.26^{1}$ & $24.14^{2}$ & & $22.6^{2}$ & & & $39.10^{2}$ & \\
\hline & $16.34^{5}$ & $46.37^{1}$ & $24.15^{2}$ & & $23.19^{1}$ & & & $42.7^{5 \mathrm{R}}$ & \\
\hline & $17.3^{2}$ & $50.29^{1}$ & $24.29^{2}$ & & $25.26^{1}$ & & & $42.27^{2}$ & \\
\hline & $17.5^{2}$ & $54.9^{1}$ & $27.19^{1}$ & & $25.30^{2}$ & & & $44.22^{1}$ & \\
\hline & $17.13^{1}$ & $54.19^{2}$ & $27.30^{2}$ & & $26.18^{1}$ & & & $46.26^{1}$ & \\
\hline & $17.21^{1}$ & $57.26^{2}$ & $28.27^{1}$ & & $27.1^{2}$ & & & 51.3 & \\
\hline & $18.25^{2}$ & $58.4^{4}$ & $28.31^{2}$ & & $27.15^{5}$ & & & $52.6^{2}$ & \\
\hline & $19.31^{2 \mathrm{R}}$ & $60.5^{4}$ & $31.13^{1}$ & & $30.5^{1}$ & & & $53.15^{1}$ & \\
\hline & $22.9^{\mathrm{R}}$ & $67.34^{2}$ & $37.23^{2}$ & & $31.1^{1}$ & & & $53.29^{1}$ & \\
\hline & $26.13^{171 R}$ & $68.22^{2}$ & $38.19^{2}$ & & $34.17^{2}$ & & & $54.25^{1}$ & \\
\hline
\end{tabular}


ADDITIONS (cont.)

\begin{tabular}{|c|c|c|c|c|c|c|c|c|c|}
\hline A & B & $\mathrm{C}$ & D & $\mathrm{E}$ & $\mathrm{F}$ & G & $\mathrm{H}$ & K & $\mathrm{L}$ \\
\hline $23 / 166 / 6^{\mathrm{R}} / \underline{1}$ & $102 / 509 / 7^{\mathrm{R}} / 3$ & $39 / 164 / 2^{\mathrm{R}}$ & $63 / 128 / 3^{\mathrm{R}} / \underline{12}$ & $18 / 52$ & $48 / 77 / 1^{\mathrm{R}}$ & $7 / 12 / 2^{\mathrm{R}}$ & 0 & $47 / 82 / 2^{\mathrm{R}} / \underline{6}$ & $3 / 12 / 1^{\mathrm{R}} / \underline{1}$ \\
\hline & ${\underline{28.13^{2}}}^{2}$ & $69.6^{1}$ & $41.33^{2}$ & & $35.19^{3}$ & & & $\underline{55.7^{3}}$ & \\
\hline & $28.18^{1}$ & $70.21^{1}$ & $42.11^{1}$ & & $35.22^{2}$ & & & $57.23^{2}$ & \\
\hline & $29.5^{2}$ & $73.25^{1}$ & $42.23^{1}$ & & $36.32^{1}$ & & & $57.25^{2}$ & \\
\hline & $29.9^{2}$ & $79.10^{1}$ & $42.26^{1}$ & & $38.18^{2}$ & & & $57.29^{7 R}$ & \\
\hline & $30.27^{2}$ & $79.12^{1}$ & $43.7^{1}$ & & $44.8^{1}$ & & & $58.33^{1}$ & \\
\hline & $31.32^{2}$ & $80.12^{1}$ & $44.26^{2}$ & & $46.36^{1}$ & & & $\underline{58.34^{2}}$ & \\
\hline & $31.44^{1}$ & $81.13^{2}$ & $47.8^{1}$ & & $46.36^{2}$ & & & $59.5^{1}$ & \\
\hline & $32.21^{1}$ & & ${\underline{47.25^{2}}}^{2}$ & & $52.16^{1}$ & & & $60.24^{2}$ & \\
\hline & $33.25^{2}$ & & $48.29^{1}$ & & $52.21^{1}$ & & & $62.2^{1}$ & \\
\hline & $34.28^{2}$ & & $\underline{50.17^{2}}$ & & $53.33^{2}$ & & & $\underline{62.11^{2}}$ & \\
\hline & $35.1^{2}$ & & $51.29^{2}$ & & $66.7^{1}$ & & & $62.30^{2}$ & \\
\hline & $35.12^{2}$ & & $53.18^{1}$ & & $76.6^{1}$ & & & $67.35^{2}$ & \\
\hline & $35.19^{3}$ & & $53.27^{2}$ & & $76.8^{1}$ & & & $68.26^{1}$ & \\
\hline & $36.12^{2}$ & & $\underline{58.32^{2}}$ & & $78.5^{1}$ & & & $\underline{68.31^{2}}$ & \\
\hline & $36.22^{1}$ & & 60.3 & & $79.20^{1}$ & & & $72.1^{1}$ & \\
\hline & $37.9^{4}$ & & ${\underline{60.8^{2}}}^{2}$ & & & & & & \\
\hline & $38.23^{9}$ & & $62.30^{4}$ & & & & & & \\
\hline & $39.17^{1}$ & & $\underline{62.31^{2}}$ & & & & & & \\
\hline & $40.5^{4}$ & & $65.13^{1}$ & & & & & & \\
\hline & $41.18^{1}$ & & $66.2^{17 \mathrm{R}}$ & & & & & & \\
\hline & $45.2^{1}$ & & $66.7^{2}$ & & & & & & \\
\hline & $45.18^{1}$ & & $70.15^{1}$ & & & & & & \\
\hline & $46.1^{2}$ & & $\underline{72.15^{3}}$ & & & & & & \\
\hline & $47.9^{153 \mathrm{R}}$ & & $75.19^{1}$ & & & & & & \\
\hline & $52.13^{1}$ & & $75.22^{2}$ & & & & & & \\
\hline & $52.25^{2}$ & & $76.16^{1}$ & & & & & & \\
\hline & $52.28^{1}$ & & $76.20^{2}$ & & & & & & \\
\hline & $54.1^{2}$ & & $78.23^{2}$ & & & & & & \\
\hline & $55.25^{2}$ & & $79.11^{2 \mathrm{R}}$ & & & & & & \\
\hline & $56.9^{2}$ & & $80.5^{5 \mathrm{R}}$ & & & & & & \\
\hline & $56.16^{2}$ & & $82.5^{2}$ & & & & & & \\
\hline & $57.20^{2}$ & & & & & & & & \\
\hline & $57.25^{8}$ & & & & & & & & \\
\hline & $58.4^{2}$ & & & & & & & & \\
\hline & ${\underline{58.21^{4}}}^{4}$ & & & & & & & & \\
\hline & $59.2^{2}$ & & & & & & & & \\
\hline & $60.1^{4}$ & & & & & & & & \\
\hline & $61.8^{1}$ & & & & & & & & \\
\hline & $62.4^{1}$ & & & & & & & & \\
\hline & $62.29^{1}$ & & & & & & & & \\
\hline & $63.5^{1}$ & & & & & & & & \\
\hline & $63.7^{1}$ & & & & & & & & \\
\hline & $63.8^{1}$ & & & & & & & & \\
\hline & $63.35^{5 \mathrm{R}}$ & & & & & & & & \\
\hline
\end{tabular}


ADDITIONS (cont.)

\begin{tabular}{|c|c|c|c|c|c|c|c|c|c|}
\hline A & B & $\mathrm{C}$ & D & $\mathrm{E}$ & $\mathrm{F}$ & G & $\mathrm{H}$ & $\mathrm{K}$ & L \\
\hline $23 / 166 / 6^{\mathrm{R}} / \underline{1}$ & $102 / 509 / 7^{\mathrm{R}} / \underline{3}$ & $39 / 164 / 2^{R}$ & $63 / 128 / 3^{\mathrm{R}} / \underline{12}$ & $18 / 52$ & $48 / 77 / 1^{\mathrm{R}}$ & $7 / 12 / 2^{\mathrm{R}}$ & 0 & $47 / 82 / 2^{\mathrm{R}} / \underline{6}$ & $3 / 12 / 1^{\mathrm{R}} / \underline{1}$ \\
\hline . & $\begin{array}{c}64.22^{1} \\
66.24^{2} \\
66.27^{2 \mathrm{R}} \\
67.35^{2} \\
68.12^{2 \mathrm{R}} \\
68.30^{3} \\
69.10^{2} \\
69.11^{2} \\
69.30^{1} \\
71.36^{1} \\
72.22^{1} \\
73.7^{1} \\
74.36^{2} \\
75.9^{2} \\
75.15^{1} \\
76.4^{1} \\
77.5^{1} \\
77.27^{2} \\
78.25^{1} \\
79.12^{1} \\
79.26^{2} \\
79.32^{2} \\
80.10^{2} \\
80.28^{1} \\
81.5^{1} \\
81.26^{1}\end{array}$ & & & & & & & & \\
\hline
\end{tabular}

SUBSTITUTIONS

\begin{tabular}{|c|c|c|c|c|c|c|c|c|c|}
\hline A & B & $\mathrm{C}$ & $\mathrm{D}$ & $\mathrm{E}$ & F & G & $\mathrm{H}$ & $\mathrm{K}$ & $\mathrm{L}$ \\
\hline $23 / \underline{1}$ & $142 / \underline{4}$ & $91 / \underline{13}$ & $116 / \underline{36}$ & 21 & $51 / \underline{3}$ & 18 & 6 & $54 / \underline{10}$ & $26 / \underline{11}$ \\
\hline$\underline{1.22}$ & 1.25 & 1.5 & 1.8 & 1.6 & 2.10 & 1.2 & 1.3 & 1.4 & 2.14 \\
\hline 1.25 & 1.36 & 1.25 & 2.18 & 6.30 & $\underline{2.39}$ & 10.31 & 8.10 & $\underline{2.21}$ & 2.30 \\
\hline 10.31 & 2.23 & 2.7 & 3.6 & 8.5 & 7.3 & 16.27 & 10.22 & 4.39 & 3.27 \\
\hline 16.21 & 3.8 & 2.20 & 3.27 & 10.5 & 7.5 & 19.25 & 27.10 & 6.19 & 11.5 \\
\hline 12.29 & 3.13 & $\underline{2.38}$ & 4.16 & 16.11 & 7.9 & 23.21 & 56.21 & $\underline{7.6}$ & 16.32 \\
\hline 14.14 & 3.22 & 3.3 & 5.1 & 23.28 & 7.30 & 25.21 & 58.11 & 8.32 & 25.7 \\
\hline 25.2 & 3.28 & $\underline{3.16}$ & 5.2 & 27.1 & 8.27 & 33.29 & & 9.12 & 25.21 \\
\hline 31.35 & 4.17 & 3.19 & 6.19 & 27.35 & 8.32 & 35.20 & & 10.31 & 31.38 \\
\hline 37.16 & 4.22 & 3.20 & $\underline{7.4}$ & 28.1 & 11.18 & 36.27 & & 12.26 & $\underline{31.39}$ \\
\hline 37.26 & 5.30 & 3.27 & 8.1 & 28.29 & $14.5(2)$ & 36.30 & & $\underline{13.2}$ & 38.27 \\
\hline 40.5 & 6.15 & 5.27 & 8.10 & 29.12 & 14.22 & 37.18 & & $\underline{14.19}$ & $\underline{44.18}$ \\
\hline 41.31 & 6.16 & 6.24 & 9.9 & 29.17 & 16.1 & 38.21 & & 14.26 & $\underline{46.4}$ \\
\hline 50.4 & 6.34 & $\underline{6.28}$ & 9.16 & 36.25 & 16.54 & $47.10(2)$ & & 17.8 & $\underline{46.32}$ \\
\hline
\end{tabular}


SUBSTITUTIONS (cont.)

\begin{tabular}{|c|c|c|c|c|c|c|c|c|c|}
\hline A & B & $\mathrm{C}$ & D & $\mathrm{E}$ & F & G & $\mathrm{H}$ & $\mathrm{K}$ & $\mathrm{L}$ \\
\hline $23 / \underline{1}$ & $142 / \underline{4}$ & $91 / \underline{13}$ & $116 / \underline{36}$ & 21 & $51 / \underline{3}$ & 18 & 6 & $54 / \underline{10}$ & $26 / \underline{11}$ \\
\hline 53.4 & 6.36 & $\underline{6.29}$ & 9.29 & 38.27 & 17.5 & 47.22 & & 19.4 & 46.37 \\
\hline 55.10 & 7.25 & 7.24 & 10.33 & 39.16 & 17.13 & 48.6 & & 19.16 & $\underline{47.3}$ \\
\hline 70.5 & 7.28 & $\underline{8.14}$ & 11.16 & 39.26 & 19.26 & 64.24 & & 22.13 & 47.15 \\
\hline 71.35 & 7.35 & 8.20 & 11.22 & 54.3 & 21.8 & 82.10 & & 23.3 & 50.24 \\
\hline 72.3 & 8.28 & 8.23 & 11.33 & 56.21 & $\underline{21.29}$ & & & 23.39 & $\underline{50.32}$ \\
\hline 72.19 & 9.2 & $\underline{9.4}$ & 12.15 & 57.23 & 22.26 & & & 24.29 & 52.14 \\
\hline 75.27 & 9.8 & 9.8 & 12.27 & 72.12 & 23.15 & & & 24.32 & $\underline{57.29}$ \\
\hline 77.8 & 9.11 & 9.25 & $\underline{12.29}$ & 80.30 & 23.20 & & & 25.19 & $\underline{64.14}$ \\
\hline 78.30 & 10.15 & $\underline{9.31}$ & 13.30 & & 24.1 & & & 25.27 & $\underline{70.6}$ \\
\hline \multirow[t]{35}{*}{81.15} & 11.28 & 10.22 & 14.38 & & 24.7 & & & 26.2 & $\underline{72.12}$ \\
\hline & 13.29 & 13.22 & 14.39 & & 24.13 & & & 27.2 & 72.17 \\
\hline & 14.3 & 14.10 & 15.4 & & 25.1 & & & 27.10 & 76.1 \\
\hline & 14.22 & $\underline{14.18}$ & 16.53 & & 25.7 & & & 27.24 & 76.19 \\
\hline & 15.7 & 16.5 & $\underline{16.56}$ & & $\underline{25.12}$ & & & 28.3 & \\
\hline & 16.4 & 16.26 & 17.4 & & 25.31 & & & 28.4 & \\
\hline & 16.7 & 17.24 & 21.23 & & 27.7 & & & 28.29 & \\
\hline & 16.25 & 17.28 & 23.20 & & 28.7 & & & 30.21 & \\
\hline & 17.7 & 17.24 & 23.26 & & 28.20 & & & 32.27 & \\
\hline & 18.2 & 18.40 & 25.18 & & 32.36 & & & 37.32 & \\
\hline & 18.6 & 20.15 & 25.20 & & 33.3 & & & 38.16 & \\
\hline & 18.7 & 20.21 & 27.3 & & 33.8 & & & 43.39 & \\
\hline & 19.11 & 20.28 & $\underline{27.8}$ & & 34.2 & & & $\underline{44.21}$ & \\
\hline & 19.25 & 21.4 & $\underline{27.22}$ & & 36.5 & & & 45.20 & \\
\hline & 19.33 & 21.22 & $\underline{27.23}$ & & 36.6 & & & 48.15 & \\
\hline & 20.15 & 21.29 & 27.29 & & 37.10 & & & 50.32 & \\
\hline & 21.3 & 23.15 & 27.40 & & 37.31 & & & $\underline{52.20}$ & \\
\hline & 22.15 & 24.18 & 28.6 & & 38.23 & & & $\underline{57.3}$ & \\
\hline & 22.16 & 25.20 & $\underline{30.8}$ & & 40.9 & & & 58.21 & \\
\hline & 22.21 & 27.4 & 30.24 & & 40.28 & & & 58.33 & \\
\hline & 23.26 & $\underline{31.11}$ & 30.29 & & 52.16 & & & $\underline{58.22}$ & \\
\hline & 24.10 & 31.19 & 31.15 & & 57.3 & & & 62.32 & \\
\hline & 25.3 & 33.27 & $\underline{31.39}$ & & 57.19 & & & 63.36 & \\
\hline & 25.18 & 34.2 & 32.32 & & 60.25 & & & $\underline{64.26}$ & \\
\hline & 25.19 & 34.18 & 34.3 & & 65.2 & & & 69.16 & \\
\hline & 25.25 & 34.21 & 34.17 & & 69.17 & & & 70.15 & \\
\hline & 26.3 & 34.22 & 34.18 & & 76.19 & & & 70.18 & \\
\hline & 27.4 & 35.20 & 36.26 & & 82.15 & & & $\underline{74.26}$ & \\
\hline & 27.36 & 35.30 & 37.28 & & & & & 77.26 & \\
\hline & 27.37 & 37.22 & 40.7 & & & & & 78.12 & \\
\hline & 28.4 & 37.29 & 41.14 & & & & & 81.14 & \\
\hline & 28.5 & 37.33 & $\underline{42.5}$ & & & & & 81.25 & \\
\hline & 28.9 & 38.15 & 42.12 & & & & & & \\
\hline & 28.16 & 39.25 & 43.7 & & & & & & \\
\hline & 28.29 & 40.3 & 44.10 & & & & & & \\
\hline
\end{tabular}


SUBSTITUTIONS (cont.)

\begin{tabular}{|c|c|c|c|c|c|c|c|c|c|}
\hline A & B & $\mathrm{C}$ & $\mathrm{D}$ & $\mathrm{E}$ & $\mathrm{F}$ & G & $\mathrm{H}$ & $\mathrm{K}$ & $\mathrm{L}$ \\
\hline $23 / \underline{1}$ & $142 / \underline{4}$ & $91 / \underline{13}$ & $116 / \underline{36}$ & 21 & $51 / \underline{3}$ & 18 & 6 & $54 / \underline{10}$ & $26 / \underline{11}$ \\
\hline & 29.18 & 43.7 & 44.23 & & & & & & \\
\hline & 30.15 & 43.11 & $\underline{45.8}$ & & & & & & \\
\hline & 30.17 & 43.26 & $\underline{45.25}$ & & & & & & \\
\hline & 30.30 & 45.15 & $\underline{45.25}$ & & & & & & \\
\hline & 30.33 & 46.21 & $\underline{46.34}$ & & & & & & \\
\hline & 31.17 & 46.25 & $\underline{46.35}$ & & & & & & \\
\hline & 32.13 & 46.36 & 48.14 & & & & & & \\
\hline & $32.24(2)$ & 48.14 & 48.26 & & & & & & \\
\hline & 33.27 & 51.37 & $\underline{48.31}$ & & & & & & \\
\hline & 34.18 & $\underline{55.6}$ & 49.5 & & & & & & \\
\hline & $34.22(2)$ & $\underline{55.33}$ & 50.5 & & & & & & \\
\hline & 35.3 & 56.24 & 50.30 & & & & & & \\
\hline & $35.26(2)$ & 57.34 & 51.1 & & & & & & \\
\hline & 35.30 & 58.2 & 51.20 & & & & & & \\
\hline & 36.34 & 60.2 & $\underline{52.2}$ & & & & & & \\
\hline & 37.8 & 64.3 & $\underline{52.3}$ & & & & & & \\
\hline & 39.7 & 68.15 & 52.17 & & & & & & \\
\hline & 39.20 & 69.15 & $\underline{52.18}$ & & & & & & \\
\hline & $39.30(2)$ & 70.10 & $\underline{52.25}$ & & & & & & \\
\hline & 40.1 & 70.11 & 52.28 & & & & & & \\
\hline & 40.13 & 70.14 & 53.3 & & & & & & \\
\hline & 41.28 & 70.24 & 53.21 & & & & & & \\
\hline & 41.37 & 71.2 & 54.17 & & & & & & \\
\hline & 43.2 & 71.32 & $\underline{55.6}$ & & & & & & \\
\hline & 44.12 & 73.21 & $\underline{55.7}$ & & & & & & \\
\hline & $\underline{44.21}$ & 73.22 & 55.22 & & & & & & \\
\hline & 45.5 & 74.24 & 57.32 & & & & & & \\
\hline & 45.17 & 76.6 & $\underline{57.34}$ & & & & & & \\
\hline & 47.19 & 76.21 & $\underline{58.18}$ & & & & & & \\
\hline & 47.21 & $\underline{80.31}$ & $\underline{58.32}$ & & & & & & \\
\hline & 48.22 & 81.24 & 59.20 & & & & & & \\
\hline & 50.22 & 81.25 & $\underline{62.18}$ & & & & & & \\
\hline & 51.27 & 81.26 & $\underline{62.30}$ & & & & & & \\
\hline & 51.34 & 81.30 & $\underline{63.17}$ & & & & & & \\
\hline & 53.12 & & $\underline{64.33}$ & & & & & & \\
\hline & 53.26 & & $66.16(2)$ & & & & & & \\
\hline & 53.31 & & 66.36 & & & & & & \\
\hline & $\underline{54.10}$ & & 67.9 & & & & & & \\
\hline & 54.19 & & $\underline{67.18}$ & & & & & & \\
\hline & 55.31 & & 68.13 & & & & & & \\
\hline & $56.9(1)$ & & $\underline{68.30}$ & & & & & & \\
\hline
\end{tabular}


SUBSTITUTIONS (cont.)

\begin{tabular}{|c|c|c|c|c|c|c|c|c|c|}
\hline A & B & $\mathrm{C}$ & D & $\mathrm{E}$ & $\mathrm{F}$ & G & $\mathrm{H}$ & $\mathrm{K}$ & $\mathrm{L}$ \\
\hline $23 / \underline{1}$ & $142 / \underline{4}$ & $91 / \underline{13}$ & $116 / \underline{36}$ & 21 & $51 / \underline{3}$ & 18 & 6 & $54 / \underline{10}$ & $26 / \underline{11}$ \\
\hline & 56.21 & & $\underline{69.10}$ & & & & & & \\
\hline & 56.29 & & 70.25 & & & & & & \\
\hline & 56.30 & & 72.6 & & & & & & \\
\hline & 57.32 & & $\underline{72.7}$ & & & & & & \\
\hline & 58.3 & & $\underline{72.25}$ & & & & & & \\
\hline & 59.5 & & 74.13 & & & & & & \\
\hline & 59.18 & & 75.7 & & & & & & \\
\hline & 61.10 & & $\underline{75.20}$ & & & & & & \\
\hline & 61.13 & & 75,31 & & & & & & \\
\hline & $\underline{62.6}$ & & $\underline{76.13}$ & & & & & & \\
\hline & 62.32 & & 77.25 & & & & & & \\
\hline & 63.10 & & $\underline{78.29}$ & & & & & & \\
\hline & 64.12 & & 79.27 & & & & & & \\
\hline & 64.17 & & 80.13 & & & & & & \\
\hline & 64.21 & & 80.19 & & & & & & \\
\hline & 66.31 & & 82.6 & & & & & & \\
\hline & 67.2 & & 82.10 & & & & & & \\
\hline & 67.10 & & & & & & & & \\
\hline & 67.34 & & & & & & & & \\
\hline & 68.4 & & & & & & & & \\
\hline & 71.8 & & & & & & & & \\
\hline & 71.40 & & & & & & & & \\
\hline & 72.26 & & & & & & & & \\
\hline & 73.19 & & & & & & & & \\
\hline & 75.4 & & & & & & & & \\
\hline & 75.13 & & & & & & & & \\
\hline & 75.17 & & & & & & & & \\
\hline & 76.2 & & & & & & & & \\
\hline & 76.12 & & & & & & & & \\
\hline & 77.19 & & & & & & & & \\
\hline & 77.33 & & & & & & & & \\
\hline & 78.2 & & & & & & & & \\
\hline & 78.27 & & & & & & & & \\
\hline & 79.22 & & & & & & & & \\
\hline & 79.26 & & & & & & & & \\
\hline & $\underline{79.29}$ & & & & & & & & \\
\hline & 79.30 & & & & & & & & \\
\hline & 80.30 & & & & & & & & \\
\hline & 82.17 & & & & & & & & \\
\hline & 82.28 & & & & & & & & \\
\hline
\end{tabular}


TRANSPOSITIONS

\begin{tabular}{|c|c|c|c|c|c|c|c|c|c|}
\hline A & B & $\mathrm{C}$ & D & E & $\mathrm{F}$ & G & $\mathrm{H}$ & K & $\mathrm{L}$ \\
\hline 2 & 3 & 5 & 20 & 2 & 13 & 0 & 0 & 7 & 0 \\
\hline 17.7 & 4.21 & 7.22 & 3.18 & 56.4 & 7.27 & & & 4.21 & \\
\hline 72.35 & 8.40 & 7.34 & 9.4 & 58.20 & 16.42 & & & 4.23 & \\
\hline & 62.6 & 9.4 & 13.20 & & 18.41 & & & 28.33 & \\
\hline & & 14.11 & 14.10 & & 19.37 & & & 40.17 & \\
\hline & & 14.14 & 14.29 & & 23.35 & & & 43.12 & \\
\hline & & & 30.30 & & 24.28 & & & 55.24 & \\
\hline & & & 35.20 & & $27.25(2)$ & & & 79.16 & \\
\hline & & & 36.7 & & 29.1 & & & & \\
\hline & & & 43.29 & & 29.3 & & & & \\
\hline & & & 44.13 & & 37.14 & & & & \\
\hline & & & 44.33 & & 43.37 & & & & \\
\hline & & & 47.12 & & 57.10 & & & & \\
\hline & & & 55.6 & & & & & & \\
\hline & & & 55.36 & & & & & & \\
\hline & & & 57.1 & & & & & & \\
\hline & & & 62.23 & & & & & & \\
\hline & & & 65.14 & & & & & & \\
\hline & & & 71.5 & & & & & & \\
\hline & & & 78.23 & & & & & & \\
\hline & & & 82.1 & & & & & & \\
\hline
\end{tabular}

NON-SENSE READINGS

\begin{tabular}{|c|c|c|c|c|c|c|c|c|c|}
\hline A & B & C & D & E & F & G & $\mathrm{H}$ & $\mathrm{K}$ & $\mathrm{L}$ \\
\hline 2 & 15 & 1 & 4 & 1 & 0 & 3 & 0 & 6 & 1 \\
\hline $\begin{array}{c}34.7 \\
78.29\end{array}$ & $\begin{array}{c}2.21 \\
12.8 \\
15.2 \\
16.53 \\
17.28 \\
18.20 \\
18.23 \\
20.25 \\
36.35 \\
37.19 \\
51.36 \\
56.23 \\
76.18 \\
81.4(2)\end{array}$ & 24.34 & $\begin{array}{l}32.29 \\
41.22 \\
43.14 \\
79.31\end{array}$ & 36.21 & & $\begin{array}{c}27.8 \\
35.21 \\
41.10\end{array}$ & & $\begin{array}{c}14.15 \\
27.7 \\
29.13 \\
34.17 \\
36.11 \\
81.6\end{array}$ & 19.1 \\
\hline
\end{tabular}


MARGINAL CORRECTIONS

\begin{tabular}{|c|c|c|c|c|c|c|c|c|c|}
\hline A & B & $\mathrm{C}$ & D & E & $\mathrm{F}$ & G & $\mathrm{H}$ & K & L \\
\hline 23 & 12 & 42 & 115 & 58 & 22 & 6 & 3 & 19 & 8 \\
\hline 1.33 & 5.7 & 4.40 & 1.20 & 1.33 & 4.36 & 24.24 & 27.29 & 8.26 & 23.28 \\
\hline 1.42 & 7.7 & $5.9(2)$ & 1.32 & 2.12 & 4.40 & 65.11 & 32.4 & 9.31 & 57.23 \\
\hline 5.5 & 12.1 & 12.14 & 3.25 & 3.4 & 5.3 & 66.18 & 50.5 & 11.2 & 65.11 \\
\hline 7.30 & 18.18 & 13.11 & 3.33 & 3.9 & 18.17 & 72.12 & & 18.37 & 66.6 \\
\hline 8.22 & 26.14 & 17.26 & 4.36 & 3.33 & 19.19 & 82.7 & & 23.28 & 66.18 \\
\hline 10.6 & 33.25 & 18.16 & 4.39 & 5.19 & 22.30 & 82.24 & & 24.24 & 72.12 \\
\hline 13.12 & 41.31 & 19.37 & 4.43 & 5.24 & 25.10 & & & 30.24 & 82.7 \\
\hline 22.14 & 45.21 & 22.18 & 5.1 & 6.19 & 26.5 & & & 42.16 & 82.24 \\
\hline 25.15 & 47.21 & 22.27 & 6.23 & 7.30 & 27.13 & & & 55.3 & \\
\hline 30.2 & 52.29 & 27.31 & 7.8 & 10.18 & 28.18 & & & $57.25(2)$ & \\
\hline 30.13 & 57.27 & 28.29 & 7.29 & 10.28 & 29.5 & & & 65.11 & \\
\hline 31.21 & 60.24 & 30.15 & 7.30 & 13.12 & 31.24 & & & 66.18 & \\
\hline 31.29 & & 31.7 & 8.5 & 15.1 & 31.27 & & & 69.22 & \\
\hline 32.9 & & 37.15 & 8.31 & 16.1 & 35.9 & & & 72.12 & \\
\hline 38.28 & & 37.23 & 8.33 & 16.22 & 37.15 & & & 76.20 & \\
\hline 39.17 & & 37.33 & 9.6 & 16.49 & 37.23 & & & 78.24 & \\
\hline 43.20 & & 41.31 & 9.21 & 16.50 & 49.3 & & & 82.7 & \\
\hline 45.26 & & 42.5 & 10.33 & 20.29 & 53.26 & & & 82.24 & \\
\hline 54.22 & & 45.23 & 12.14 & 21.6 & 55.5 & & & & \\
\hline 54.26 & & 46.11 & 13.20 & 22.16 & 64.17 & & & & \\
\hline 60.6 & & 49.1 & 14.6 & 22.30 & 69.10 & & & & \\
\hline 64.28 & & 49.10 & 14.8 & 25.24 & 72.12 & & & & \\
\hline \multirow[t]{20}{*}{78.1} & & 50.2 & 14.30 & 26.9 & & & & & \\
\hline & & 55.19 & 16.39 & 26.16 & & & & & \\
\hline & & 56.14 & 17.5 & 27.12 & & & & & \\
\hline & & 58.21 & 17.11 & 28.33 & & & & & \\
\hline & & 59.16 & 17.14 & 30.18 & & & & & \\
\hline & & 59.39 & 18.5 & 32.9 & & & & & \\
\hline & & 61.27 & 18.25 & 34.9 & & & & & \\
\hline & & 64.9 & 19.17 & 34.23 & & & & & \\
\hline & & 65.3 & 20.25 & 36.8 & & & & & \\
\hline & & 66.25 & 20.29 & 41.13 & & & & & \\
\hline & & 71.8 & 22.27 & 45.4 & & & & & \\
\hline & & 71.20 & 22.30 & 46.2 & & & & & \\
\hline & & 72.23 & 23.24 & 46.28 & & & & & \\
\hline & & 74.7 & 23.40 & 47.22 & & & & & \\
\hline & & 74.19 & 24.1 & 48.25 & & & & & \\
\hline & & 75.14 & 24.34 & 53.9 & & & & & \\
\hline & & 81.10 & 24.35 & 55.11 & & & & & \\
\hline & & 81.18 & 25.24 & 55.28 & & & & & \\
\hline & & 82.17 & 27.24 & 55.34 & & & & & \\
\hline & & & 27.31 & 56.9 & & & & & \\
\hline
\end{tabular}


206

Viacheslav V. LytVynenko

MARGINAL CORRECTIONS (cont.)

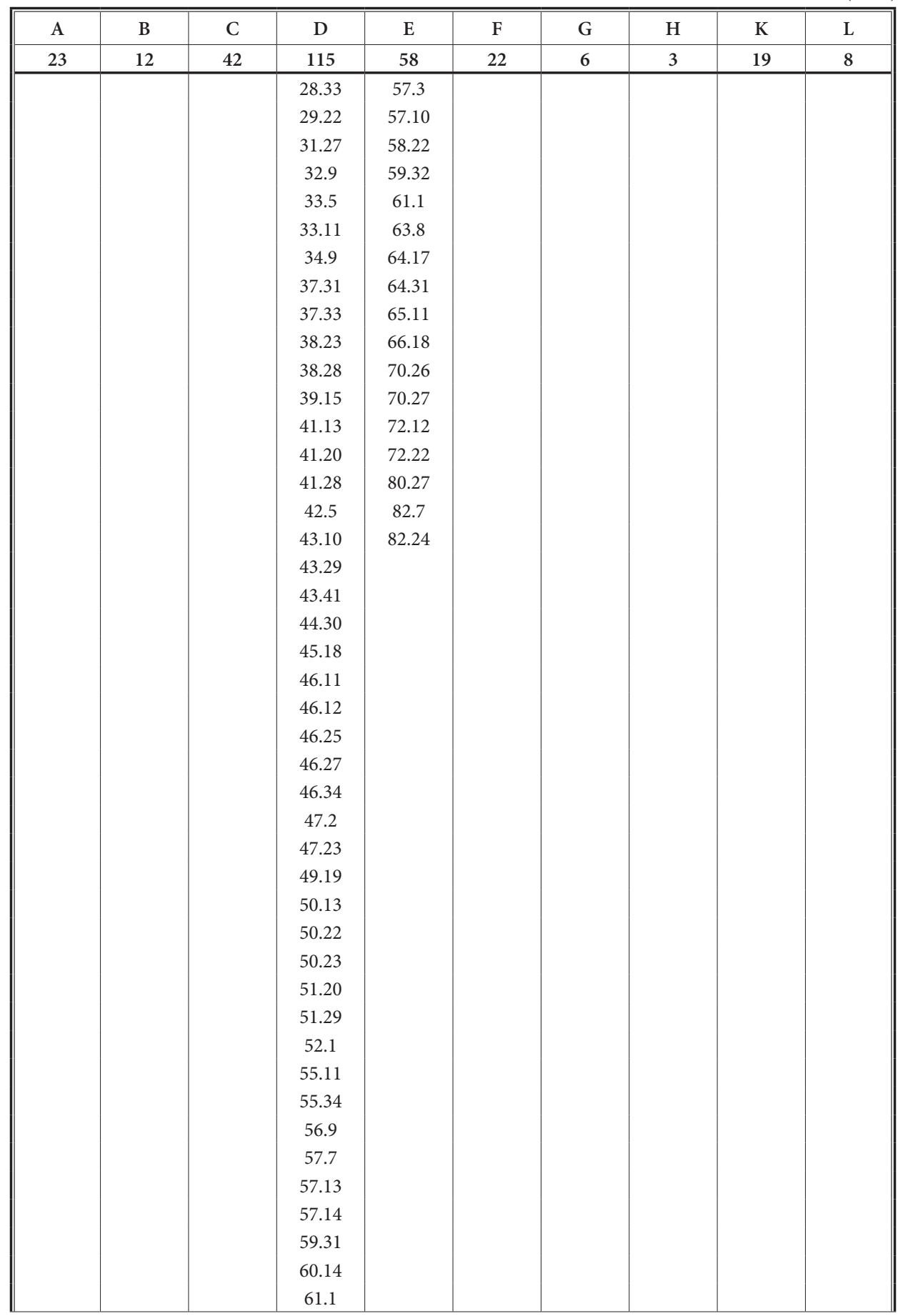




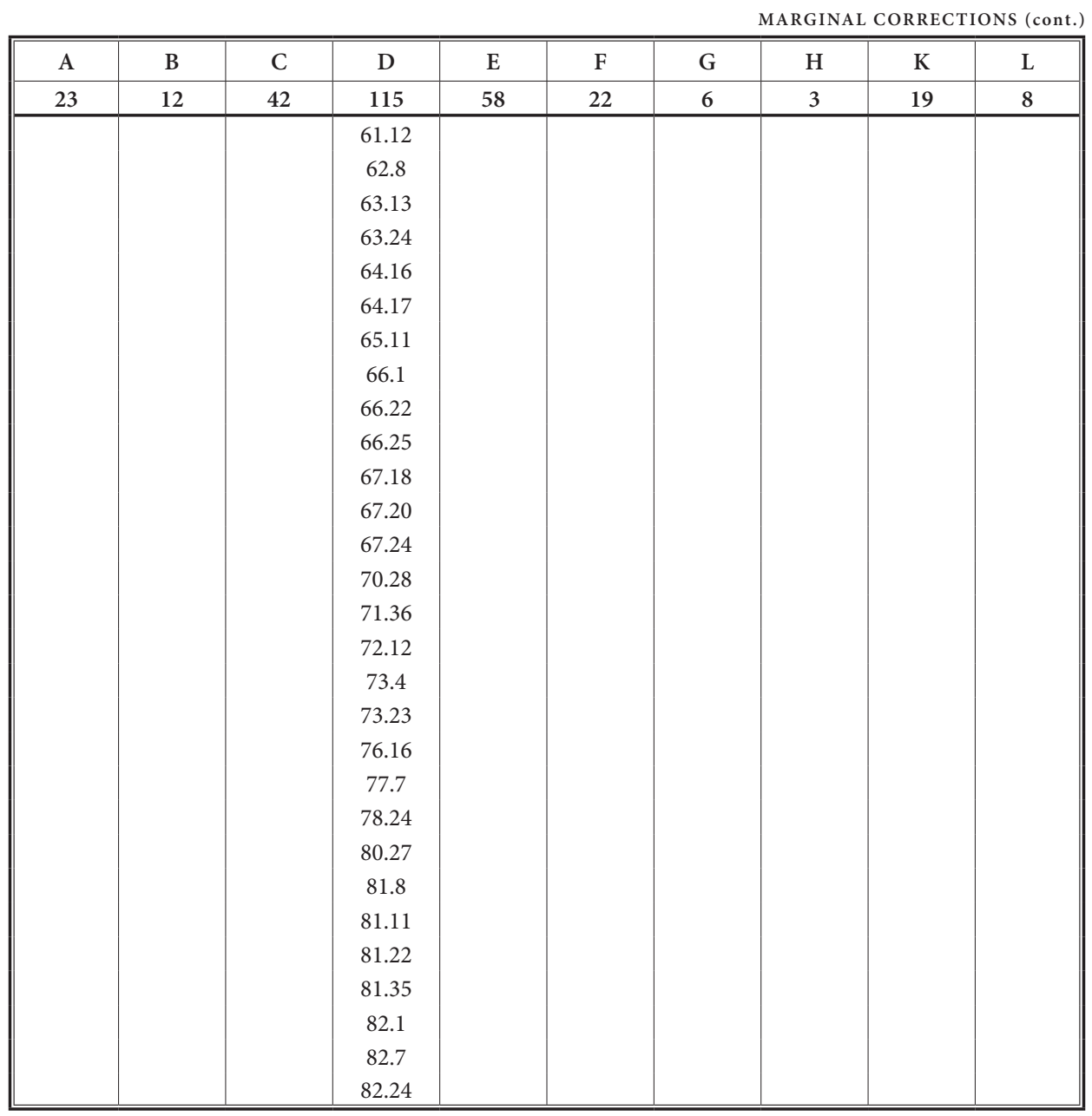

MARGINAL NOTES

\begin{tabular}{|c|c|c|c|c|c|c|c|c|c|}
\hline A & B & C & D & E & F & G & $\mathrm{H}$ & K & L \\
\hline 5 & $3 / 2^{\mathrm{L}}$ & 2 & 0 & 0 & 0 & 1 & 0 & $16 / 12^{\mathrm{L}}$ & $16 / 12^{\mathrm{L}}$ \\
\hline 8.39 & 57.3 & 44.5 & & & & 23.36 & & 8.27 & 8.25 \\
\hline 9.18 & $65.11^{\mathrm{L}}$ & 44.6 & & & & & & $23.22^{\mathrm{L}}$ & $23.22^{\mathrm{L}}$ \\
\hline 18.4 & $78.2^{\mathrm{L}}$ & & & & & & & 23.36 & 23.36 \\
\hline 18.24 & & & & & & & & $24.34^{\mathrm{L}}$ & $24.34^{\mathrm{L}}$ \\
\hline 46.39 & & & & & & & & $27.28^{\mathrm{L}}$ & $27.28^{\mathrm{L}}$ \\
\hline & & & & & & & & $27.38^{\mathrm{L}}$ & $27.38^{\mathrm{L}}$ \\
\hline & & & & & & & & $28.12^{\mathrm{L}}$ & $28.12^{\mathrm{L}}$ \\
\hline & & & & & & & & $36.7^{\mathrm{L}}$ & $35.12^{\mathrm{L}}$ \\
\hline & & & & & & & & $37.22^{\mathrm{L}}$ & $37.22^{\mathrm{L}}$ \\
\hline & & & & & & & & 43.7 & 43.7 \\
\hline
\end{tabular}


MARGINAL NOTES (cont.)

\begin{tabular}{|c|c|c|c|c|c|c|c|c|c|}
\hline A & B & $\mathrm{C}$ & D & $\mathrm{E}$ & $\mathrm{F}$ & G & $\mathrm{H}$ & K & $\mathrm{L}$ \\
\hline 5 & $3 / 2^{\mathrm{L}}$ & 2 & 0 & 0 & 0 & 1 & 0 & $16 / 12^{\mathrm{L}}$ & $16 / 12^{\mathrm{L}}$ \\
\hline & & & & & & & & $\begin{array}{c}43.12 \\
43.13^{\mathrm{L}} \\
43.18^{\mathrm{L}} \\
44.7^{\mathrm{L}} \\
67.15^{\mathrm{L}} \\
81.31^{\mathrm{L}}\end{array}$ & $\begin{array}{c}43.12 \\
43.13^{\mathrm{L}} \\
43.18^{\mathrm{L}} \\
44.7^{\mathrm{L}} \\
67.15^{\mathrm{L}} \\
81.31^{\mathrm{L}}\end{array}$ \\
\hline
\end{tabular}

DELETIONS

\begin{tabular}{|c|c|c|c|c|c|c|c|c|c|}
\hline $\mathbf{A}$ & B & $\mathrm{C}$ & D & E & F & G & $\mathbf{H}$ & K & $\mathbf{L}$ \\
\hline $20 / 16^{\mathrm{R}}$ & $3 / 1^{\mathrm{R}}$ & $11 / 5^{\mathrm{R}}$ & $11 / 7^{\mathrm{R}}$ & $63 / 23^{R}$ & $8 / 2^{\mathrm{R}}$ & $6 / 3^{R}$ & 1 & $5 / 3^{R}$ & 1 \\
\hline 1.32 & $2.8^{\mathrm{R}}$ & 8.14 & $3.27^{\mathrm{R}}$ & $1.25^{\mathrm{R}}$ & 2.10 & 3.10 & \multirow[t]{33}{*}{8.33} & $4.32^{\mathrm{R}}$ & \multirow[t]{33}{*}{78.8} \\
\hline $7.36^{\mathrm{R}}$ & 52.29 & $9.10^{\mathrm{R}}$ & $15.12^{\mathrm{R}}$ & 1.39 & $30.8^{\mathrm{R}}$ & 5.4 & & $19.35^{\mathrm{R}}$ & \\
\hline $19.19^{\mathrm{R}}$ & 58.20 & 12.3 & 19.36 & 2.36 & 45.4 & 18.17 & & $37.3^{\mathrm{R}}$ & \\
\hline $19.34^{\mathrm{R}}$ & & $18.32^{\mathrm{R}}$ & $27.1^{\mathrm{R}}$ & 3.4 & 45.24 & $34.11^{\mathrm{R}}$ & & $50.1(2)$ & \\
\hline 20.5 & & 22.17 & 32.30 & 3.5 & 54.22 & $39.18^{\mathrm{R}}$ & & 79.4 & \\
\hline $21.16^{\mathrm{R}}$ & & 42.21 & $38.8^{\mathrm{R}}$ & $3.27^{\mathrm{R}}$ & $79.17^{\mathrm{R}}$ & $70.5^{\mathrm{R}}$ & & & \\
\hline $24.19^{\mathrm{R}}$ & & $46.25^{\mathrm{R}}$ & $42.5^{\mathrm{R}}$ & $4.16^{\mathrm{R}}$ & 81.18 & & & & \\
\hline $32.26^{\mathrm{R}}$ & & 50.2 & 46.12 & 5.13 & 81.24 & & & & \\
\hline $36.20^{\mathrm{R}}$ & & $55.28^{\mathrm{R}}$ & 46.35 & $10.26^{\mathrm{R}}$ & & & & & \\
\hline $40.2^{\mathrm{R}}$ & & 56.22 & $65.26^{\mathrm{R}}$ & $12.15^{\mathrm{R}}$ & & & & & \\
\hline $43.25^{\mathrm{R}}$ & & $76.2^{\mathrm{R}}$ & $71.9^{\mathrm{R}}$ & 13.7 & & & & & \\
\hline 50.22 & & & & $16.15^{\mathrm{R}}$ & & & & & \\
\hline 57.20 & & & & $17.15^{\mathrm{R}}$ & & & & & \\
\hline $61.21^{\mathrm{R}}$ & & & & 19.10 & & & & & \\
\hline $67.35^{\mathrm{R}}$ & & & & $19.34^{\mathrm{R}}$ & & & & & \\
\hline $69.23^{\mathrm{R}}$ & & & & 19.36 & & & & & \\
\hline $74.22^{\mathrm{R}}$ & & & & $20.10^{\mathrm{R}}$ & & & & & \\
\hline $76.6^{\mathrm{R}}$ & & & & 21.14 & & & & & \\
\hline $76.21^{\mathrm{R}}$ & & & & 21.19 & & & & & \\
\hline $76.26^{\mathrm{R}}$ & & & & $22.17^{\mathrm{R}}$ & & & & & \\
\hline & & & & 23.11 & & & & & \\
\hline & & & & 23.17 & & & & & \\
\hline & & & & $24.2^{\mathrm{R}}$ & & & & & \\
\hline & & & & $25.9^{\mathrm{R}}$ & & & & & \\
\hline & & & & 28.10 & & & & & \\
\hline & & & & $31.25^{\mathrm{R}}$ & & & & & \\
\hline & & & & 31.28 & & & & & \\
\hline & & & & $31.32^{\mathrm{R}}$ & & & & & \\
\hline & & & & 31.34 & & & & & \\
\hline & & & & 31.36 & & & & & \\
\hline & & & & $33.9^{\mathrm{R}}$ & & & & & \\
\hline & & & & $33.12^{\mathrm{R}}$ & & & & & \\
\hline & & & & 35.12 & & & & & \\
\hline
\end{tabular}


DELETIONS (cont.)

\begin{tabular}{|c|c|c|c|c|c|c|c|c|c|}
\hline A & B & C & D & E & $\mathbf{F}$ & G & $\mathbf{H}$ & $\mathbf{K}$ & $\mathbf{L}$ \\
\hline $20 / 16^{\mathrm{R}}$ & $3 / 1^{\mathrm{R}}$ & $11 / 5^{\mathrm{R}}$ & $11 / 7^{\mathrm{R}}$ & $63 / 23^{\mathrm{R}}$ & $8 / 2^{\mathrm{R}}$ & $6 / 3^{\mathrm{R}}$ & 1 & $5 / 3^{\mathrm{R}}$ & 1 \\
\hline & & & & $\begin{array}{c}35.32^{\mathrm{R}} \\
36.7 \\
38.8^{\mathrm{R}} \\
38.14 \\
39.11 \\
45.24 \\
46.1 \\
48.25 \\
49.17 \\
49.19^{\mathrm{R}} \\
51.21 \\
52.1 \\
52.21 \\
54.4 \\
55.21 \\
56.4 \\
56.16^{\mathrm{R}} \\
57.10 \\
57.29 \\
58.1 \\
58.19 \\
59.29 \\
63.32 \\
65.26^{\mathrm{R}} \\
70.23 \\
71.9^{\mathrm{R}} \\
71.36 \\
71.40 \\
74.18 \\
78.33^{\mathrm{R}}\end{array}$ & & & & & \\
\hline
\end{tabular}

ERASURES

\begin{tabular}{||c|c|c|c|c|c|c|c|c|c||}
\hline \hline $\mathbf{A}$ & $\mathbf{B}$ & $\mathbf{C}$ & $\mathbf{D}$ & $\mathbf{E}$ & $\mathbf{F}$ & $\mathbf{G}$ & $\mathbf{H}$ & $\mathbf{K}$ & $\mathbf{L}$ \\
\hline $\mathbf{3 / \mathbf { 1 } ^ { \mathrm { R } }}$ & $\mathbf{1}$ & $\mathbf{5}$ & $\mathbf{2 4}$ & $\mathbf{1 4}$ & $\mathbf{8}$ & $\mathbf{0}$ & $\mathbf{0}$ & $\mathbf{0}$ & $\mathbf{1}$ \\
\hline 19.21 & 3.28 & 3.31 & 7.31 & 3.13 & 3.31 & & & & 25.5 \\
$23.1^{\mathrm{R}}$ & & 9.4 & 8.33 & 4.39 & 4.42 & & & & \\
51.15 & & 12.9 & 9.20 & 7.31 & 16.4 & & & & \\
& & 40.4 & 14.15 & 8.3 & 16.49 & & & & \\
& & 71.22 & 17.14 & 10.14 & 17.21 & & & & \\
& & & 17.21 & 11.17 & 26.23 & & & & \\
& & & 18.27 & 13.4 & 35.21 & & & & \\
& & & 19.10 & 21.4 & 81.23 & & & & \\
& & & 36.15 & 25.21 & & & & & \\
\hline
\end{tabular}


ERASURES (cont.)

\begin{tabular}{|c|c|c|c|c|c|c|c|c|c|}
\hline A & B & C & D & E & F & G & $\mathbf{H}$ & $\mathbf{K}$ & $\mathbf{L}$ \\
\hline $3 / 1^{\mathrm{R}}$ & 1 & 5 & 24 & 14 & 8 & 0 & 0 & 0 & 1 \\
\hline & & & 39.18 & 45.3 & & & & & \\
\hline & & & 39.26 & 54.6 & & & & & \\
\hline & & & 42.27 & 55.12 & & & & & \\
\hline & & & 44.16 & 67.11 & & & & & \\
\hline & & & 45.13 & 74.30 & & & & & \\
\hline & & & 46.1 & & & & & & \\
\hline & & & 51.21 & & & & & & \\
\hline & & & 54.6 & & & & & & \\
\hline & & & 55.12 & & & & & & \\
\hline & & & 55.21 & & & & & & \\
\hline & & & 57.10 & & & & & & \\
\hline & & & 57.29 & & & & & & \\
\hline & & & 59.25 & & & & & & \\
\hline & & & 67.11 & & & & & & \\
\hline & & & 71.26 & & & & & & \\
\hline
\end{tabular}

INTERLINEAR CORRECTIONS

\begin{tabular}{||c|c|c|c|c|c|c|c|c|c||}
\hline \hline A & B & C & D & E & F & G & H & K & L \\
\hline $\mathbf{3 0}$ & $\mathbf{1 0}$ & $\mathbf{2 3}$ & $\mathbf{6 2}$ & $\mathbf{1 2 0}$ & $\mathbf{1 1}$ & $\mathbf{1 4}$ & $\mathbf{4}$ & $\mathbf{1 6}$ & $\mathbf{3}$ \\
\hline 9.10 & 20.13 & 6.15 & 3.26 & 3.18 & 10.28 & 1.34 & 13.27 & 7.34 & 68.22 \\
13.5 & 20.28 & 8.18 & 6.22 & 3.26 & 20.4 & 1.39 & 17.4 & 12.29 & 68.27 \\
16.10 & 43.10 & 22.17 & 7.26 & 7.21 & 27.9 & 6.17 & 35.10 & 13.11 & 70.22 \\
18.25 & 43.22 & 23.5 & 7.37 & 7.26 & 37.35 & 7.15 & 46.10 & 13.12 & \\
18.29 & 43.41 & 24.15 & 9.4 & 7.28 & 47.18 & 16.20 & & 14.41 & \\
27.26 & 44.14 & 28.32 & 9.19 & 8.28 & 65.23 & 18.6 & & 32.21 & \\
29.15 & 47.10 & 39.4 & 10.14 & 8.33 & 67.40 & 23.31 & & 33.14 & \\
30.35 & 50.24 & 41.5 & 10.18 & 9.4 & 69.3 & 37.16 & & 43.19 & \\
32.24 & 75.23 & 46.16 & 10.25 & 9.6 & 76.26 & 37.26 & & 44.23 & \\
35.8 & 81.24 & 47.18 & 10.34 & 9.8 & 77.11 & 44.10 & & 44.24 & \\
35.9 & & 50.18 & 13.12 & 10.1 & 78.14 & 48.24 & & 44.25 & \\
37.2 & & 50.22 & 16.33 & 10.18 & & 62.1 & & 55.12 & \\
42.4 & & 51.18 & 18.33 & 10.25 & & 62.29 & & 63.30 & \\
48.13 & & 57.2 & 19.21 & 10.34 & & 70.1 & & 71.35 & \\
52.29 & & 57.32 & 19.22 & 11.7 & & & & 78.8 & \\
54.15 & & 58.11 & 22.6 & 11.25 & & & & 79.4 & \\
$57.18(2)$ & & 68.31 & 23.39 & 12.3 & & & & & \\
58.17 & & 70.1 & 24.16 & 12.21 & & & & & \\
64.19 & & 72.1 & 27.35 & 13.7 & & & & & \\
65.17 & & 75.7 & 31.34 & 13.11 & & & & & \\
$70.14(2)$ & & 80.19 & 34.3 & 14.6 & & & & & \\
71.37 & & 80.21 & 37.16 & 14.6 & & & & & \\
\hline
\end{tabular}


INTERLINEAR CORRECTIONS (cont.)

\begin{tabular}{|c|c|c|c|c|c|c|c|c|c|}
\hline A & B & $\mathrm{C}$ & D & $\mathrm{E}$ & $F$ & G & $\mathrm{H}$ & $\mathrm{K}$ & $\mathrm{L}$ \\
\hline 30 & 10 & 23 & 62 & 120 & 11 & 14 & 4 & 16 & 3 \\
\hline 76.22 & & 81.12 & 40.11 & 14.31 & & & & & \\
\hline 76.38 & & & 41.4 & 15.7 & & & & & \\
\hline 76.39 & & & 42.11 & 16.12 & & & & & \\
\hline 77.10 & & & 43.7 & 16.40 & & & & & \\
\hline 77.32 & & & 43.19 & 18.10 & & & & & \\
\hline 82.11 & & & 44.32 & 18.17 & & & & & \\
\hline & & & 45.13 & 18.33 & & & & & \\
\hline & & & 46.7 & 19.22 & & & & & \\
\hline & & & 46.22 & 19.32 & & & & & \\
\hline & & & 47.10 & 20.25 & & & & & \\
\hline & & & 47.22 & 20.27 & & & & & \\
\hline & & & $49.7(2)$ & 22.6 & & & & & \\
\hline & & & 52.15 & 22.9 & & & & & \\
\hline & & & 52.35 & $22.15(2)$ & & & & & \\
\hline & & & 53.19 & 23.11 & & & & & \\
\hline & & & 54.8 & 23.19 & & & & & \\
\hline & & & 54.17 & 23.24 & & & & & \\
\hline & & & 55.34 & 23.26 & & & & & \\
\hline & & & 56.15 & 23.39 & & & & & \\
\hline & & & 56.36 & 23.40 & & & & & \\
\hline & & & 57.5 & 24.1 & & & & & \\
\hline & & & 57.27 & 27.14 & & & & & \\
\hline & & & 58.28 & 27.35 & & & & & \\
\hline & & & $58.29(2)$ & 28.3 & & & & & \\
\hline & & & 59.41 & 30.15 & & & & & \\
\hline & & & 62.17 & 31.9 & & & & & \\
\hline & & & 62.20 & 31.12 & & & & & \\
\hline & & & 62.25 & 31.22 & & & & & \\
\hline & & & 62.27 & 31.23 & & & & & \\
\hline & & & 64.27 & 31.28 & & & & & \\
\hline & & & 64.28 & 32.6 & & & & & \\
\hline & & & 68.20 & 32.10 & & & & & \\
\hline & & & 70.26 & 34.3 & & & & & \\
\hline & & & 71.3 & 36.15 & & & & & \\
\hline & & & 72.33 & 37.16 & & & & & \\
\hline & & & 73.15 & 37.26 & & & & & \\
\hline & & & 75.14 & 38.28 & & & & & \\
\hline & & & 81.10 & 39.31 & & & & & \\
\hline & & & & 40.11 & & & & & \\
\hline & & & & 40.15 & & & & & \\
\hline & & & & 40.24 & & & & & \\
\hline & & & & 45.13 & & & & & \\
\hline
\end{tabular}


INTERLINEAR CORRECTIONS (cont.)

\begin{tabular}{|c|c|c|c|c|c|c|c|c|c|}
\hline $\mathbf{A}$ & B & $\mathrm{C}$ & D & $\mathrm{E}$ & $F$ & G & $\mathbf{H}$ & $\mathrm{K}$ & $\mathrm{L}$ \\
\hline 30 & 10 & 23 & 62 & 120 & 11 & 14 & 4 & 16 & 3 \\
\hline & & & & $\begin{array}{c}46.7 \\
47.10 \\
48.16 \\
49.7(2) \\
50.13 \\
50.25 \\
51.20 \\
51.29 \\
52.4 \\
52.35 \\
53.9 \\
54.8 \\
54.13 \\
56.13 \\
56.15 \\
56.16 \\
56.36 \\
57.5(2) \\
58.11 \\
58.16 \\
58.29(2) \\
58.32 \\
59.29 \\
59.31 \\
62.11 \\
63.7 \\
63.34 \\
64.28 \\
64.32 \\
65.14 \\
66.22 \\
67.29 \\
68.2 \\
68.20 \\
68.28 \\
71.27 \\
71.29 \\
71.40 \\
72.22 \\
72.33\end{array}$ & & & & & \\
\hline
\end{tabular}


INTERLINEAR CORRECTIONS (cont.)

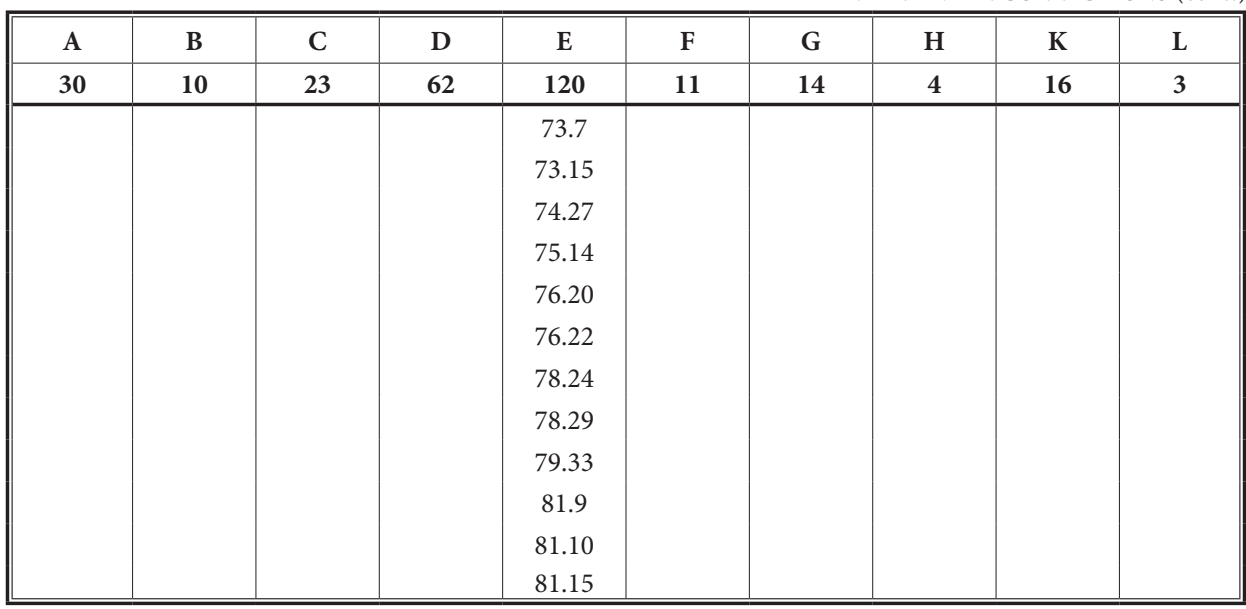

CORRECTIONS WITHIN THE TEXT

\begin{tabular}{||c|c|c|c|c|c|c|c|c|c||}
\hline $\mathbf{A}$ & $\mathbf{B}$ & $\mathbf{C}$ & $\mathbf{D}$ & $\mathbf{E}$ & $\mathbf{F}$ & $\mathbf{G}$ & $\mathbf{H}$ & $\mathbf{K}$ & $\mathbf{L}$ \\
\hline $\mathbf{0}$ & $\mathbf{0}$ & $\mathbf{0}$ & $\mathbf{4}$ & $\mathbf{8}$ & $\mathbf{1}$ & $\mathbf{1}$ & $\mathbf{1}$ & $\mathbf{7}$ & $\mathbf{0}$ \\
\hline & & & 6.25 & 6.19 & 49.25 & 23.28 & 17.26 & 35.21 & \\
& & & 51.18 & $18.21(2)$ & & & & 44.8 & \\
& & & 74.18 & 22.21 & & & & 46.15 & \\
& & & 74.30 & 33.14 & & & & 49.5 & \\
& & & & 33.16 & & & & 49.13 & \\
& & & & 34.9 & & & & 58.3 & \\
& & & & 81.28 & & & & 82.10 & \\
\hline
\end{tabular}

\section{Abbreviations}

\section{Abbreviations in the Manuscripts}

\section{Libraries and Archives}

GIM

State Historical Museum, Moscow (Государственный исторический музей)

RGB

Russian State Library, Moscow (Российская государственная библиотека)

RNB

Russian National Library, Saint Petersburg (Российская национальная библиотека) 


\section{Manuscript Collections}

Nik.

Collection of P.N. Nikiforov (RGB, Moscow)

Ovč.

Collection of P.A. Ovčinnikov (RGB, Moscow)

Pog

Collection of N.P. Pogodin (RNB, Saint-Petersburg)

Sin.

Collection of Sinodal Library (GIM, Moscow)

Sof.

Collection of Sophia Library (RNB, Saint-Petersburg)

Sol.

Collection of Solovetsk Monastery (RNB, Saint-Petersburg)

Tsa.

Collection of Tsar manuscripts (GIM, Moscow)

Vol.

Collection of Iosifo-Volokolamsk Monastery (RGB, Moscow)

\section{Other Abbreviations}

$\begin{array}{ll}\text { f., ff. } & \text { Leaf, leaves } \\ \text { MS, MSS } & \text { Manuscript(s) } \\ r=\text { recto } & \text { Right hand side } \\ \text { sec. }=\text { secundus } & \text { Second } \\ \text { sine } & \text { Without, except } \\ v=\text { verso } & \text { Left hand side } \\ \text { VMČ (BMY) } & \text { Great Menaion Reader (Velikie Minei Četii) } \\ > & \text { Omitted }\end{array}$

\section{Bibliography}

\section{Primary Sources}

Athanasius of Alexandria, Oratio II contra Arianos. Old Slavonic Version and English Translation, ed. et trans. V.V. Lytvynenko, Turnhout 2019 [= Patrologia Orientalis, 248 (56.3)].

Athanasius Werke, vol. I.1, Die dogmatischen Schriften, Lfg. 1, Epistula ad episcopos Aegypti et Libyae, ed. K. Metzler, K. SAvvidis, Berlin-New York 1996.

Athanasius Werke, vol. I.1, Die dogmatischen Schriften, Lfg. 2, Orationes I et II contra Arianos, ed. K. MetZler, K. Savvidis, Berlin-New York 1998. 
Athanasius Werke, vol. I.1, Die dogmatischen Schriften, Lfg. 3, Oratio III contra Arianos, ed. K. MetzLER, K. SAVvidis, Berlin-New York 2000.

Biblija 1499 goda i Biblija v sinodalnom perevode s illjustracijami. Dejanija svjatych Apostolov et al., vol. VIII, Moskva 1992.

Biblija 1499 goda i Biblija v sinodalnom perevode s illjustracijami. Gospoda našego Iisusa Christa Svjatoe Evangelie ot Matfeja, Marka, Luki, Ioanna, vol. VII, Moskva 1992.

Biblija 1499 goda i Biblija v sinodalnom perevode s illjustracijami. Psaltyr', vol. IV, Moskva 1997.

\section{Secondary Literature}

Aleskejev A.I., Religioznye dviženia na Rusi poslednej treti XVI - načala XVI v.: strigolniki i židovstvujuščie, Moskva 2012.

Fonkič B.L., Grečesko-russkie kulturnye svjazi v XV-XVII vv. (Grečeskie rukopisi v Rossii), Moskva 1977.

GaLČEnko M.G., Vtoroe južnoslavjanskoe vlijanie v drevneruskoj knižnosti. (Grafiko-orfografičeskie priznaki vtorogo južnoslavjanskogo vlijanija i chronologija ich pojavlenija $v$ drevnerusskich rukopisjach konca XIV - pervoj poloviny XV v.), [in:] Knižnaja kultura. Knigopisanie. Nadpisi na ikonach drevnej Rusi, ed. M.G. GaLČEnKo, Moskva-Sankt-Peterburg 2001, p. 325-420.

Die Grossen Lesemenäen des Metropoliten Makarij. Uspenskij spisok, vol. I, 1-8 Mai, ed. E. WeIHer et al., Freiburg 2007 [= Monumenta Linguae Slavicae Dialecti Veteris, 51].

Iosif (Hieromonk), Opis' rukopisej perenesennych iz biblioteki Iosifova monastyrja v biblioteku Moskovskoj duchovnoj akademii, Moskva 1882.

Lytvynenko V.V., Athanasius' Orations against the Arians: Theological Glosses in Two Slavonic Manuscripts, "Преславска книжовна школа” / "Preslavska knižovna škola” 19, 2019, p. 77-101.

Pravoslavie Ukrainy i Moskovskoj Rusi v XVI-XVII vekach: Obščeje i različnoe, ed. M.V. DMITRIEv, Moskva 2012.

Romanchuk R., Once Again on the Greek Workbook of Timofei Veniaminov, Fifteenth-Century Novgorod Monk, [in:] Monastic Traditions. Selected Proceedings of the Fourth International Hilandar Conference. The Ohio State University 1998, ed. C.E. Gribble, P. Matejic, Columbus 2003, p. 263-303.

Sedelnikov L.D., K izučeniju 'Slova kratka' i dejatel'nosti dominikanca Veniaminova, “Известия Отделения русского языка и словесности" / "Izvestija Otdelenija russkogo jazyka i slovesnosti” 30, 1925, p. 205-225.

Smorgunova E., Sostaviteli i piscy Gennadijevskoj Biblii, [in:] Biblija v duchovnoj žyzni, istorii $i$ kul'ture Rossii i pravoslavnogo slavjanskogo mira. Sbornik materialov meždunarodnoj konferencii k 500-letiju Gennadievskoj Biblii, Moskva, 21-26 sentjabrja 1999 g., Moskva 2001, p. 92-118.

Socinianism and its Role in the Culture of XVI th to XVIII ${ }^{\text {th }}$ Centuries, ed. L. SzczuckI, WarsawLodz 1983.

Tsvetaev D.I., Protestanstvo I pretestanstvo v Rosii do epochi preobrazovanij, Moskva 1890.

Westcott B.F., Hort F.J.A., The New Testament in the Original Greek, vol. II, ${ }^{2}$ London 1896. 


\begin{abstract}
This article introduces the readers to the scribal habits/practices in ten Slavonic manuscripts that contain Athanasius' Second Oration against the Arians. These scribal habits are classified and analyzed according to eleven categories: (1) omissions, (2) additions, (3) substitutions, (4) transpositions, (5) non-sense readings, (6) marginal corrections, (7) marginal notes, (8) deletions, (9) erasures, (10) interlinear corrections, and (11) corrections within the text. The analysis of each manuscript is accompanied with the statistical tables that summarize the collected data according to these eleven categories, and there is a longer summary table in the Appendix. Of the ten manuscripts, two are analyzed in more detail as a way of illustrating how the Orations were copied and read in medieval times, and how theological concerns and local contexts affected the scribe's interaction with the text.
\end{abstract}

Keywords: Scribal habits, Athanasius of Alexandria, Orations against the Arians

Viacheslav V. Lytvynenko

Charles University Černá 646/9

11555 Prague, Czech Republic vyacheslav.lytvynenko@gmail.com 